University of Louisville

ThinkIR: The University of Louisville's Institutional Repository

Electronic Theses and Dissertations

$12-2016$

\title{
Plant community responses to the removal of Lonicera maackii from an urban woodland park.
}

Elihu H. Levine

University of Louisville

Follow this and additional works at: https://ir.library.louisville.edu/etd

Part of the Forest Biology Commons

\section{Recommended Citation}

Levine, Elihu H., "Plant community responses to the removal of Lonicera maackii from an urban woodland park." (2016). Electronic Theses and Dissertations. Paper 2613.

https://doi.org/10.18297/etd/2613

This Master's Thesis is brought to you for free and open access by ThinkIR: The University of Louisville's Institutional Repository. It has been accepted for inclusion in Electronic Theses and Dissertations by an authorized administrator of ThinkIR: The University of Louisville's Institutional Repository. This title appears here courtesy of the author, who has retained all other copyrights. For more information, please contact thinkir@louisville.edu. 
PLANT COMMUNITY RESPONSES TO THE REMOVAL OF LONICERA MAACKII FROM AN URBAN WOODLAND PARK

\author{
By Elihu H. Levine \\ B. A., Earlham College, 2005

\begin{abstract}
A Thesis
Submitted to the Faculty of the

College of Arts and Sciences of the University of Louisville

In Partial Fulfillment of the Requirements

for the Degree of
\end{abstract} \\ Master of Science \\ in Biology \\ Department of Biology \\ University of Louisville \\ Louisville, Kentucky
}

December 2016 

PLANT COMMUNITY RESPONSES TO THE REMOVAL OF LONICERA MAACKII FROM AN URBAN WOODLAND PARK

By

Elihu H. Levine

B.A., Earlham College, 2005

A Thesis Approved on

November 16, 2016

By the following Thesis Committee:

Dr. Margaret Carreiro, Director

Dr. Sarah Emery

Dr. C. Andrew Day 


\section{ACKNOWLEDGEMENTS}

For incredible patience, assistance, advice and enlightening instruction I thank my advisor Dr. Margaret Carreiro. Thank you, as well, to Dr. Sarah Emery and to Dr. C. Andrew Day for all of their help as member of my thesis committee. I also need to thank Major Waltman and the Louisville Olmsted Parks Conservancy's Woodlands Restoration Team for their time and the effort needed to create and maintain the study sites in a busy park. My grateful thanks also go to the numerous undergraduate research assistants who gave generously of their time and labor: Kayla Wiseman, Andrew Frink, Ryan King, Elizabeth Mortenson, Brad Brasher and Thad Schroeder. Finally, thank you to my wife, my parents, and all of the family and friends who encouraged me through the long process. 


\section{ABSTRACT \\ PLANT COMMUNITY RESPONSES TO THE REMOVAL OF LONICERA MAACKII FROM AN URBAN WOODLAND PARK}

November 16, 2016

Elihu H. Levine

Impacts of Lonicera maackii on native forest communities have been widely researched, but longterm responses of plant communities to the removal of this exotic shrub have not been extensively evaluated. The Louisville Olmsted Parks Conservancy removes exotic shrubs and vines to restore ecological processes and native species in the woodlands of Cherokee Park. Paired-plots were established in 2008 to gather baseline herb, vine, tree, and shrub community data. Honeysuckle was removed from one plot of each pair in 2009 and community data were gathered again in 2013. Native herb cover and richness, vine cover, and tree sapling abundance increased where honeysuckle had been removed. Higher summer herb cover was also correlated to sites with longer duration of L. maackii invasion and a more open tree canopy above. This suggests a legacy of $L$. maackii invasion on the forest community structure impacting herb communities, even 5 years after its removal. 


\section{TABLE OF CONTENTS}

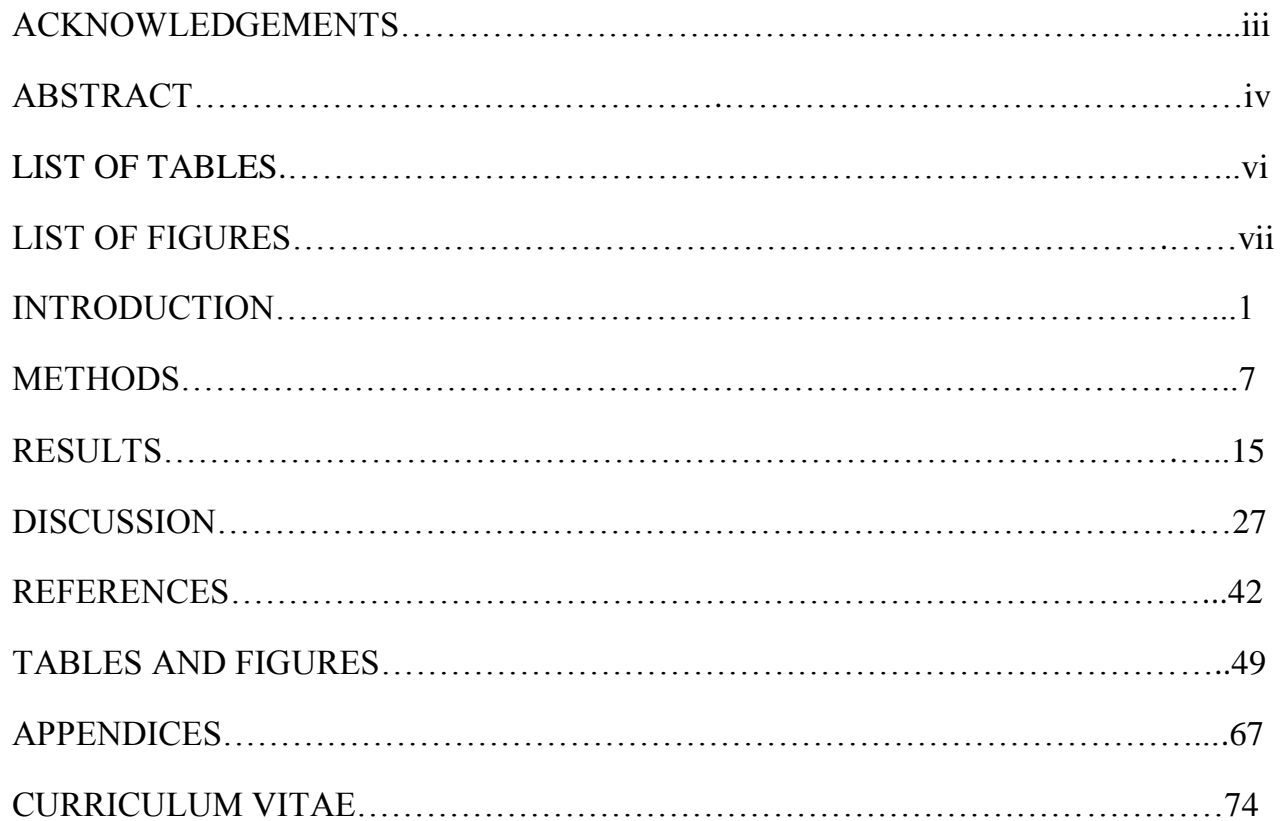




\section{LIST OF TABLES}

Table 1. Spring and summer (2013) herb community characteristics...................49

Table 2. Herb and vine richness, diversity and cover in 2008 and $2013 \ldots \ldots \ldots \ldots \ldots . . . .50$

Table 3. Light related factors and key plant responses in removal plots .................51

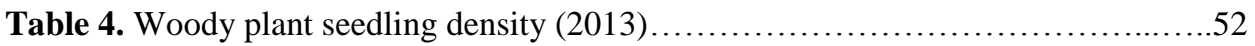

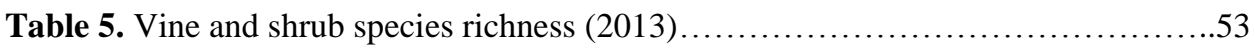

Table 6. Spring and summer (2013) Vine Cover..................................54

Table 7. Shrub, vine and tree seedling and saplings in 2008 and $2013 \ldots \ldots \ldots \ldots \ldots \ldots . .55$

Table 8. Tree seedling and sapling richness and density $(2013) \ldots \ldots \ldots \ldots \ldots \ldots \ldots \ldots . \ldots \ldots$

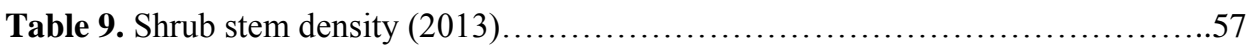

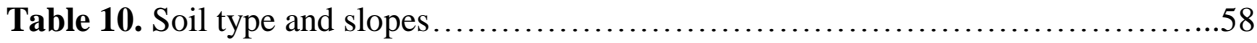

Table 11. Sunlight-proxies and summer (2013) herb cover in removal plots............59

Table 12. Soil Series and classification of soils at sites...............................60

Table 13. Canopy cover measurements........................................61

Table 14. Summer plant community in "shade" and "open" removal plots.............62 


\section{LIST OF FIGURES}

Figure 1. Map of study sites in Cherokee Park, Louisville, KY .........................63

Figure 2. Spring and summer (2013) exotic and native herb cover in removal plots ...64

Figure 3. Herb cover in removal plots regressed with community characteristics........65

Figure 4. Herb cover (2013) in removal plots and duration of invasion...............66 


\section{INTRODUCTION}

As development near natural areas increases, invasive exotic plants have been identified as significant problems in many parts of the world (Vitousek et al.1997). D'Antonio and Vitousek (1992) put forth the argument that anthropogenic reductions of biogeographic dispersal barriers have allowed massive introductions of exotic species with a corresponding increase in "invasions" by these exotic species in theirnovel territories. This has allowed species that evolved in isolation from one another to interact in a common environment. Not all exotic species are defined as invasive. A presidential Executive Order in 1999 defined invasive species as "Those species whose introduction does, or is likely to, cause economic or environmental harm or harm to human health" (Clinton 1999). Some invasive species are estimated to cause billions of dollars-worth of economic damage (Vitousek et al. 1997). Invasive plant management accounts for more than half of the budgets for some parks and are a "serious threat" to more than half of the parks in the US National Park System (NPS) (D’Antonio and Meyerson 2002). In 2009, the NPS listed more than 4,550 invasive plants, approximately $70 \%$ of the invasive species found in the USA, documented in the parks that it manages (National Park Service 2009). While the traits that cause individual species to become "invasive" are not fully understood, much effort has gone into understanding the effects of invasion (Tillman 1997; Davis et al. 2000; Sakai et al. 2001; Levine et al.2003; Callaway and Maron 2006).

In some cases invasive species may alter ecosystem processes in such a way as to facilitate their own spread, or make the ecosystem more vulnerable to invasion by another species (Vitousek et al.1997).

Ehrenfeld (2003) suggests that invasive plant species frequently alter biomass and net primary production, water cycling, and carbon $(\mathrm{C})$ and nitrogen $(\mathrm{N})$ availability and cycling in habitats where they have been introduced. Such alterations of nutrients and soil processes may have dramatic effects on native species (Yelenik and Levine 2011) sometimes causing positive feedbacks that increase the abundance of the invasive species themselves (Smith and Reynolds 2012). 
The increasing loss of natural areas due to human development and climate change (Vitousek et al. 1997) places an increasing importance on the preservation of biodiversity in protected natural areas in preserves and parklands (Scott et al. 2001; Bruner et al.2001; Hansen et al. 2002). There is evidence that positioning preserves within a larger landscape of protected land will reduce the likelihood of invasion by exotic plants (Pyšek et al. 2002). In a synthesis of threats posed to wilderness parks in the US National Park System, Cole and Landres (1996) concluded that smaller, more isolated, areas situated within a disturbed landscape matrix would see higher likelihood of invasion by non-native species, especially those areas with higher rates of human visitation. These criteria describe parks in urban areas: smaller size due to premium land prices, isolation from other natural areas by dense human development, location in a dynamic urban landscape of shifting development, disturbance, and visitation patterns. This similarity suggests that urban parks will be among the areas that are more vulnerable to exotic species invasions. Despite often being the most species-rich green spaces in urban zones, parks often contain high proportions of exotic species- particularly exotic plants (Nielsen et al. 2014).

The urban landscape is not only a barrier isolating fragmented green spaces, it can also be a source for exotic species. The horticultural use of exotic plants for private property has resulted in the introduction of many invasive exotic plants in North America (Reichard and White 2001). Indeed one such plant, Lonicera maackii (Rupr.) Herder (Caprifoliaceae), has spread dramatically in eastern North America since its introduction from Northern China into U.S. gardens in the late 1890's (Luken and Thieret 1996). Trisel (1997) noted that this shrub has become naturalized in 24 states of the United States and the Canadian Province of Ontario. In 2016, the United States Department of Agriculture's PLANTS database (NRCS 2016) reported L. maackii populations in 26 eastern states plus the District of Columbia and Oregon on the west coast (as well as Ontario). Commonly known as Amur Honeysuckle, L. maackii is an upright shrub that grows up to six to seven meters high, creating a dense understory canopy that is not commonly found in much of the deciduous forests of North America (Hartman and McCarthy 2008).

Notably, L. maackii benefits from an extended leaf phenology. In addition to better freeze tolerance, L. maackii leaf development in the spring occurs some two to three weeks earlier than similar competitors that are native to Kentucky (McEwan et al. 2009). Leaf abscission in the fall occurs three to four weeks after the main tree canopy pulse in Louisville, Kentucky (Trammell et al. 2012). Some reports 
have suggested that $L$. maackii may retain leaves as much as two months after some native canopy trees (Quercus rubra and Acer saccharum) drop their leaves (Blair and Stowasser 2010). This distinct timing difference may be key to L. maackii's competitive success through a variety of mechanisms (Smith 2013). For example, the extended phenology of $L$. maackii has been shown to reduce native plant diversity and abundance and alter the behavior of pollinators to native herbs (McKinney and Goodell 2010). The relative timing of the phenologies, therefore, can be key to determining the relative success of native and exotic species of plants (Rejmanek 2013; Cleland et al. 2013).

There is a robust body of literature documenting the negative impacts of L. maackii establishment on the plant communities of eastern deciduous woodlands of North America. L. maackii invasion manifestly reduces the realized niches for many other native species as evidenced by the depauperate subcanopy and forest floor plant strata observed in invaded forests (Collier et al.2002). Gould and Gorchov (2000) found reduced survival and fecundity of three native herbs in proximity to L. maackii (Galium aparine and Impatiens pallida both found in this study, plus Pilea pumila). Forests long invaded by $L$. maackii may see reduced densities and species richness for herbs and tree seedlings suggesting that invasion may have significant consequences for the community's species composition in the future (Collier et al. 2002; Gorchov and Trisel 2003; Hartman and McCarthy 2004; Hartman and McCarthy 2008).

The addition of this one newly dominant species into a previously under-exploited niche may even reduce the growth rates of mature canopy trees (Hartman and McCarthy 2007). L. maackii invasion is associated with an approximately $25 \%$ reduction in total foliar leaf litter biomass and L. maackii may comprise a higher proportion of the litter that is present (Trammell et al. 2012). The leaf litter that $L$. maackii produces contains more nitrogen and lower C:N ratios (Blair and Stowasser 2010; Trammell et al. 2012), and so decays faster than native tree leaf litters in both aquatic (McNeish et al. 2012; Fargen et al. 2015) and terrestrial ecosystems (Arthur et al. 2012; Poulette and Arthur 2012; Trammell et al. 2012). This could result in an alteration in availability of safe sites for seed germination and seedling survival for some plants as both reduced canopy litter input and faster litter decomposition resulted in thinner leaf litter layers (Facelli and Pickett 1991; Baker and Murray 2010; Masters and Emery 2015).

Some evidence suggests that L. maackii may have allelopathic potential, at least against native herbaceous seedlings (Dorning and Cipollini 2006; Cipollini and Dorning 2008; Cipollini et al. 2008; 
Cipollini et al. 2009; Cipollini and Bohrer 2016). However, while chemicals with allelopathic potential are found in L. maackii roots and foliage, demonstrating long-lasting in situ allelopathic effects is methodologically difficult given the confounding factors of direct competition. Some attempts to separate above- and below-ground effects of $L$. maackii have been made, and data shows some below-ground negative interactions, but the significant portion of the interactions seem to result from above-ground competition for light (Gorchov and Trisel 2003; Cipollini et al. 2009). Therefore it is likely that the invasion success of this shrub is due to a combination of effects on the native plant community involving competition for light, ability to take advantage of autogenically altered nutrient dynamics in the soil, and the potential for reduced seed safe sites- all altering the native plant community composition.

Since parks and other sensitive woodlands are often managed specifically for desirable herb species and to improve tree health and recruitment (Cole and Landres 1996; Bruner et al.2001; Carreiro and Zipperer 2011; Nielsen et al.2014), it is imperative to quantify the success of efforts to remove L. maackii from these forests as a strategy to ensure a more desirable successional trajectory for woody and herbaceous native plant communities. When considering the implications of removing L. maackii, managers must take into consideration two major alterations in the habitat that may constrain restoration success and affect their management goals. The first is that the invasion itself may have already caused ecosystem-level changes such as more rapid soil N cycling (McEwan et al.2012), higher earthworm biomass (Pipal 2014), thinner leaf litter layers (Trammel et al. 2012), and reductions in the native plant seed bank. In some cases these changes have the potential to remain as legacies even after the shrub's removal. The second is the removal of the L. maackii itself, which is a considerable disturbance to the lower strata of the forest in its own right. The elimination of the upright woody structure and its canopy permits greater light penetration to the forest floor. This can potentially benefit non-target exotic plants as well as native plants, depending on the community composition, the extant propagule-bank in the soil, and proximity of nearby propagule sources.

A recent review suggests that exotic species can often account for as many as half of the plant species identified in urban parks (Nielsen et al. 2014). Increased densities of L. maackii itself have been associated with proximity to urban areas, and may contribute greatly to the seed bank (Borgmann and 
Rodewald 2005; White et al. 2014; Trammel and Carreiro 2011). As a result, identifying the potential for exotic plants to become invasive after competitive release due to L. maackii removal is of great concern.

A recent review of the literature (McNeish and McEwan 2016) underscored the robust understanding of the effects of L. maackii invasion on woodlands, but it left unresolved the legacy, if any, of the invasion after removal of the shrub. Their synthesis predicts that invaded forests are likely to experience altered community structure and function, even altered successional trajectories. However, there is very little data on the state of forest communities when L. maackii is removed. Most research has concentrated on describing the effects of $L$. maackii on invaded forests, sometimes along a gradient of duration of invasion (Collier et al. 2002; Hartman and McCarthy 2008) or gradients of disturbance (Gould and Gorchov 2000). A few studies have focused on the efficacy of the efforts to remove L. maackii, but did not examine the community as a whole (Loeb et al. 2010), or were limited to following recovery for just a couple of growing seasons (Hartman and McCarthy 2004). Some efforts have been made to follow plant community recovery after L. maackii removal, but few have extended past one growing season of response (Owen et al. 2005), or examined the response of more than a couple of species (Gould and Gorchov 2000). The few studies that have examined plant communities over more than a few seasons generally focused on only one component of the community (Luken et al. 1997a and b; Runkle et al.2007).

The flush of spring ephemerals often die back as the tree canopy fully leafs out, leading to distinct spring and summer herb communities. Luken et al. (1997a) noted that measuring in the spring compared to the summer in one year increased the ground-level species richness, likely due to the inclusion of some of the ephemeral spring herbs, many of which are of high conservation value. Due to differences in abiotic factors (light penetration through the canopy, temperatures, forest floor litter cover, access to pollinators) these communities might react to the disturbance of L. maackii in different ways. One recent study examined the herb and tree seedling responses to L. maackii removal, but did not separate spring ephemeral from summer herb communities, instead treating all herbs as part of one community with only peak cover reported over an 8 year interval (Boyce 2015). Boyce's (2015) data make it very clear that plant community responses after just one or two years can vary drastically from those of 3-5 years post-removal and that these responses may vary depending on the intensity of $L$. maackii invasion. 
Specifically, managers need to know whether the alterations to the available niches of native plants are short-term and reversible once L. maackii is removed, or if the simple fact of invasion has the potential to permanently alter the plant communities that arise (i.e., whether L. maackii invasion results in a legacy of reduced niche availability for native species known to have colonized the forest in the past). If the native plant community cannot recover on its own, then managers will have to combine shrub removal with planting efforts of desirable native herbs and tree species to achieve a future target community. This study seeks to quantify the responses by the forest plant community five years after removal of L. maackii shrubs from a managed urban park woodland. There are three over-arching questions:

In the fifth growing season since being released from L. maackii domination:

1. Did either of the spring or summer native herbaceous plant communities exhibit an increase in abundance or diversity?

2. Did woody plant communities (vines, trees, or shrubs) exhibit an increase in recruitment and diversity of seedlings and saplings?

3. To what extent did the resulting plant community become dominated by exotic species, including L. maackii itself?

4. Do variables associated with light influence the resulting plant community structure after removal of L. maackii?

5. Did longevity of occupation by L. maackii explain variation in plant community responses after its removal? 


\section{METHODS}

\section{Background and site description}

This study occurred in Cherokee and Seneca Parks (158 ha and 135 ha, respectively) located in Louisville, KY, (Latitude $38.25 \mathrm{~N}$, Longitude $-85.76 \mathrm{~W}$ ), a city with a merged city-county population of over 756,000 in 2013 (U.S. Census Bureau 2013). These contiguous parks were established in the late 19th and early 20th century and have had a history of human recreational use and of planting both native and non-native species (Carreiro and Zipperer 2011). In 1974, half of the tree canopy of Cherokee Park was destroyed by an F4 tornado, which likely accelerated re-colonization by exotic vines and shrubs (Carreiro and Zipperer 2011). Therefore, much of the area of these mixed deciduous woodlands consists of secondary forests with Acer saccharum, Fraxinus americana and Celtis occidentalis as dominant tree species (M. Carreiro, unpublished).

In 2005, the Louisville Olmsted Parks Conservancy (LOPC) began a campaign of park-wide invasive plant removals. When this present study was initiated in 2008 , these deciduous woodlands were in a highly degraded state due to long-term invasion by exotic vines and shrubs, particularly Lonicera maackii. This study was initiated in cooperation with the LOPC to establish long-term plots to determine the extent to which the plant community might recover from Lonicera shrub removal, and without further removals or plant additions by management, the extent to which that community would become dominated by native or exotic plant species.

\section{Experimental design}

In 2008, ten sites were established in different management areas of these woodlands, representing a range of slopes, aspects and honeysuckle densities in these adjacent parks (Figure 1). In order to collect baseline data on vegetation and soils no manipulations occurred during this first year of the study. Each paired-plot site consisted of two permanent $10 \times 10 \mathrm{~m}$ plots, which were separated by a buffer-strip (three- 
meter minimum) and a five-meter buffer between their perimeters and any management activities occurring in the rest of the forest. Each plot was divided into sixteen $2.5 \times 2.5 \mathrm{~m}$ quadrats for simplifying the quantification of vegetation, leaf litter cover and collection of soil samples.

The heavily invaded areas of the park were small and easily accessible enough for the cut-stumpapplication method using glyphosate to be a viable strategy for park managers rather than foliar application of herbicide. Of these two common strategies for L. maackii removal, foliar application is generally used in areas either too large or too difficult to access for more intensive efforts (Hartman and McCarthy 2004; Czarapata 2005; Miller 2006). The foliar application method allows the woody structure of the invasive shrub to remain, which may provide some protection for nascent seedlings underneath (Hartman and McCarthy 2004). This, however, may harm other desirable plants in the area. Therefore, in stands where resources allow, the cut-stump-application method is often employed. The shrub is cut down as close to the ground as is feasible, then herbicide is immediately applied directly to the vascular tissue of the stump. This allows a careful applicator to avoid over-spraying and potentially damaging other sensitive or desirable plants.

In January 2009, honeysuckle shrubs were cut and removed in one randomly selected plot at each site. Lonicera stems were cut at ground level and painted with a $26 \%$ solution of the herbicide, glyphosate (N-(phosphonomethyl) glycine (Roundup). All aboveground cut shrub biomass was removed from the site to: a) make subsequent data and soil sample collection easier, b) ensure that all L. maackii shrubs were removed at one time, and c) to prevent the structure of remaining debris from providing a "ladder" for any subsequent vine growth to overtop the ground-level plant community. Discs were taken from the stumps with the largest basal-area at each plot for counting annual growth rings and thereby estimate the minimum known presence of L. maackii at that location. Discs were sanded smooth and annual growth rings were counted by three observers and averaged to obtain the reported values. These cut plots were designated "removal" and the uncut plots as "control" treatments. Our use of the term, site, refers to a single plot pair.

Three additional sites were designated reference sites and one $10 \times 10 \mathrm{~m}$ plot was established at each reference site (Figure 1). These three plots had been cleared of L. maackii by the same methods as the removal plots at least five years prior to the beginning of this study. In these three plots only, many other 
exotic plants deemed invasive (e.g. Alliaria petiolata, Ampelopsis brevipedunculata, Celastrus orbiculatus, Morus alba) had also been removed at the same time as L. maackii by either chemical herbicide application or mechanical removal (Major Waltman, personal communication).

The data for this study were collected in 2013 , in the fifth growing season after the removal treatment at eight of the original ten sites $(\mathrm{N}=8)$. By 2013, the control plots at two of the original sites had been accidentally cut by management crews. Therefore the vegetation responses for this fifth year could only be obtained for eight of the original ten paired-plot sites.

\section{Vegetation Sampling}

To characterize the understory plant community in this study, plant data were quantified as in 2008. Herb data were collected twice during the growing season: first in the spring (April 10-May 17, 2013) to capture early ephemeral species and then again in the summer (July 9-19, 2013) to assess abundance and diversity of species that develop later in the growing season. Estimates of $\%$ herb cover were collected by species for each entire plot. Woody vine cover by species was also collected in the summer. Only vine foliage below $30 \mathrm{~cm}$ in height was recorded. Since total foliage by species for herbs and woody vines is layered, it is possible to exceed $100 \%$ total cover in a plot.

Tree species were separately recorded by seedling $(<30 \mathrm{~cm}$ tall) and sapling $(>30 \mathrm{~cm}$ tall, DBH $<2.5 \mathrm{~cm}$ ) strata. Seedling and sapling data were collected between June 18 and July 3. Shrub species were quantified as the number of living stems $>30 \mathrm{~cm}$ tall from between May 8 to June 12. For shrubs with multiple branching stems only the ones that emerged from the trunk at a height less than $30 \mathrm{~cm}$ from the ground were counted. Vine and shrub seedlings were also counted between May 8 and June 12. Woody vine seedlings were those that were newly germinated and in their first year of growth (most still had cotyledons). Stems and seedlings were recorded as number per $100 \mathrm{~m}^{2}$, the area of each plot.

Plants were identified to species where possible, otherwise to genus with nomenclature following the USDA PLANTS online database (NRCS 2016). Vines in the family Vitaceae were difficult to differentiate until mature (particularly Vitis sp. vs. Ampelopsis sp.), but when possible they were separated according to species. When this wasn't possible, these seedlings were classified as Vitaceae and 
considered native to provide a conservative estimate of colonization by invasive vines in this study. The USDA PLANTS database was used to classify plants as either native or exotic for the United States and its territories in the western hemisphere.

\section{Diversity Indices}

Species richness, $\mathrm{R}$, was measured as the number of plant species identified in a plot $\left(100 \mathrm{~m}^{2}\right)$.

Diversity was calculated using two indices. The first is Shannon's Index, H':

$$
\mathrm{H}^{\prime}=\sum_{i=1}^{R}-p_{i} * \ln \left(p_{i}\right)
$$

The second diversity index is Simpson's Index, D:

$$
\mathrm{D}=\sum_{i=1}^{R} \mathrm{p}_{i}^{2}
$$

For both equations $\mathrm{R}$ is the total number of species in the plot and $p_{i}$ is the proportion of the total herb cover in the plot of species

Shannon's Evenness, J, was calculated as:

$$
\mathrm{J}=\frac{H^{\prime}}{\ln (R)}
$$

Richness was calculated for spring and summer herbs separately, vines, shrubs, and tree seedlings and saplings. Diversity (H' and D) and evenness (J) were calculated separately for each of the spring and summer herb collections, for tree seedlings, and for tree saplings.

\section{Environmental variables}

Several environmental variables that were anticipated to potentially explain vegetation responses were measured at each of the plots. These included aspect, slope, canopy cover, $\%$ bare soil (with no leaf litter cover), litter mass in late spring, and distance to nearest edge with a road or field. Aspect was measured using magnetic compass, declination $4^{\circ}$ West, taken at the center point facing down the major 
slope for each plot. The \% slope for each plot was determined using a clinometer (Suunto PM-5/360 PC; Suunto, Finland). In 2009, soils in each plot were identified to soil series by personnel from the Natural Resources Conservation Service (NRCS).

Canopy cover was estimated using a Model-C spherical Densiometer (Paul E. Lemmon, Forest Densiometers, Bartlesville, OK). Measurements were taken in 2013 (May 22-28) at the center of each control and removal plot. In 2013, densiometer readings were taken at or near ground level $(<10 \mathrm{~cm})$ to measure the light environment that might influence a seedling's growth. These readings included tree, shrub and low plant canopies. These seedling-level measurements were taken facing north in each of the center four quadrats, then averaged. Densiometer measurement were again made in 2014 (August 30) because two main types of summer plant abundance responses were observed among the different sites, and we wished to test whether correlations with tree canopy cover might explain these divergent patterns. Therefore, densiometer readings were taken at a height of $1.25 \mathrm{~m}$ to avoid most shrub canopy and obtain a better estimate of foliar cover by the tree canopy alone. These 2014 measurements were obtained as close to the center of the plot as possible with one measurement taken while facing each of the four cardinal directions then averaged (Lemmon 1956). If necessary, some measurements were taken away from the center of the plots in 2014 to avoid interference from dense shrub sub-canopy. Only densiometer data from the removal plots in 2014 measurements have been used for correlations with plant response data, although the 2014 control-plot data and 2013 data are also reported for comparison.

As part of an ancillary study the Leaf Area Index (LAI; $\mathrm{m}^{2}$ of leaves per $\mathrm{m}^{2}$ of ground area) of trees and honeysuckle shrubs collected for the 2010 growing season were gathered, while not part of the original study it was intended to provide some measure of the relative availability of light to plants below the canopy. LAI was gathered in addition to densiometer data because densiometer readings do not completely capture the 3-dimensional contribution of the leaf canopy to light extinction. LAI was estimated using the leaf litter-fall method. Leaf litter was captured weekly to monthly depending on time of year from mid-August 2010 to early April of 2011 (4 baskets per plot). LAI was measured in the lab using a LiCor area meter (LI-3100 Area Meter, Lincoln, NE, USA). The LAI for each sampling date was summed to obtain an estimate of the total canopy LAI for all woody species (trees, shrubs, vines) in the 2010 growing 
season, with shrub honeysuckle leaves separately quantified. Because the LAI data were acquired for a separate experiment, it was only measured for five of the eight sites used in this study $(\mathrm{N}=5)$ and is meant to supplement or verify the densiometer data. Only non-Lonicera leaf litter was used for LAI estimates of the tree canopy above the plots for this vegetation study.

Since the amount and distribution of litter cover on the forest floor can affect germination and growth of plants, the percent exposed soil in the forest floor was estimated visually in late spring 2013. In addition, leaf litter mass was sampled between May 29 and June 12, 2013 by collecting leaf litter at 8 random locations per $2.5 \mathrm{~m}^{2}$ quadrat (total $\mathrm{n}=128 / \mathrm{plot}$ ) using a circular template of $8.7 \mathrm{~cm}$ diameter. Leaf litter was pooled by quadrat, oven dried at $60^{\circ} \mathrm{C}$, weighed to $0.0000 \mathrm{~g}$ and calculations performed to calculate the mean $\mathrm{g}$ leaf litter $\mathrm{m}^{-2}$ plot. Fine woody debris (FWD, defined as woody stems and bark with a diameter $<5 \mathrm{~cm}$ ) was also quantified using two $25 \mathrm{~cm}$ x $25 \mathrm{~cm}$ square templates randomly placed in each $2.5 \mathrm{~m}^{2}$ quadrat collected on the same days as leaf litter mass collections. All FWD within each template was collected, pooled by quadrat, dried as per leaf litter, weighed to $0.00 \mathrm{~g}$, and plot means were calculated to determine $\mathrm{g}$ FWD $\mathrm{m}^{-2}$ per plot.

In addition, to explore the potential role of light and seed entry from the sides of the plots to explain plant community and abundance responses, the distance from the wooded plot edge to the nearest field, mown road verge, road or stream was measured. Measurements were taken from the midpoint of the downhill edge between each pair of plots in a straight line following the direction of the dominant slope out to the edge of the forest canopy.

\section{Statistical analyses}

Pairwise t-tests were used to compare data between "Control" and "Removal" treatments in 2013 using SAS (SAS Studio, SAS University Edition v2.2) Proc Ttest using the Paired statement. If data were not normally distributed according to the Shapiro-Wilk tests, the data were transformed as needed to ensure normality (allowing the use of parametric tests to preserve statistical power). Reported means \pm 1 standard error (S.E.) are untransformed. Two-tailed t-tests were performed for the diversity indices (Shannon's H' and J; Simpson's D), vine and shrub seedlings density, and total shrub stem density. Four sets of data could not be transformed to normality; instead Wilcoxon Ranked-Sign Tests were used to determine 
control vs. removal-plot differences in native vine cover, exotic and native vine species richness, and shrub species richness (total shrub species, as well as native and exotic shrub species richness). All other withinyear t-tests were one-tailed, predicting higher vegetative responses in removal plots (herb cover, species richness, woody seedling and tree sapling density, and vine cover).

Two-way ANOVAs modeling the interactions of treatment (Lonicera shrubs present or absent) and year (2008 vs. 2013) with blocking by site were performed using Proc Mixed (SAS Studio, SAS University Edition, v9.3) to examine year-to-year variation in herb cover, herb species richness, herb diversity and evenness (Shannon's H' and J), vine cover and richness, woody seedling densities, and sapling density and richness $(\mathrm{N}=8)$. In 2013, a one-factor ANOVA was used to compare the plant communities in the "open tree canopy" vs. "shaded tree canopy" removal plots $(\mathrm{N}=4$ per canopy category). The plant community variables compared in this manner were summer herb cover and richness; summer exotic herb cover; vine cover and richness; vine, shrub, and tree seedling density, sapling density; tree seedling and sapling species richness; shrub stem density; Lonicera spp. stem density: total stems, short stems (0.3-0.99m), and medium stems (1.00-1.99m).

Since total plant cover differed between removal plots, we explored whether abiotic variables associated with light could explain this variation. Pearson's product-moment correlation (r) was calculated for summer herb cover $(\%)$ and the environmental variables: canopy cover, distance from between plot edge and forest-canopy edge, LAI, and aspect using the SAS Proc Corr. Aspects were converted from compass degrees to degrees from north by subtracting any value greater than $180^{\circ}$ from $360^{\circ}$ and using the absolute value of the result, so that no value would be greater than $180^{\circ}$. Correlation involving LAI was only available for five of the eight sites as explained above.

In the fifth growing season since L. maackii removal, plant cover was found to vary between removal plots. Plants closer to ground level received a great deal of shading from taller herbs therefore herb cover was regressed against diversity (Shannon's H'), evenness (Shannon's J), and richness (R) to determine if herb cover abundance was associated with these measures of community structure. Spring and summer herb cover $(\%)$ were also regressed against the minimum known presence of L. maackii at each 
site to determine if longevity of Lonicera occupation might have left a legacy effect on these recovering communities. These regressions were calculated using SAS Proc Reg.

Reported p-values are corrected using the False Discovery Rate (FDR) to control the Type I error rate, as calculated using the SAS Proc Multtest (SAS Studio, SAS University Edition, v9.3). When FDR corrected $p$-values for interaction terms from the 2 -factor ANOVAs were significant at $\alpha=0.05$, the $p$-values of the main effects were ignored in results.

Due to the experimental design the vegetative responses of the paired plots were expected to vary by treatment and between years. General increases in plant abundance and species richness were predicted in the removal plots after five years. However, directionality (increase or decrease) in the responses of community diversity, H', and evenness, J were not posited. Significant differences between the years (2008 to 2013) but not the treatments (removal vs. control) might indicate some other confounding factor that was not explicitly measured by the study (ex. external events or alterations that affected all plots in a roughly equivalent manner). Whereas, significant differences in experimental treatment, but not year might indicate some factor intrinsic to the sites that differed at the plot scale in a consistent manner over the five years. It should also be noted that the 2008 data collection took place before the removal treatment occurred, therefore no difference in the treatment component in 2008 was presumed. A significant difference for the interaction of terms year and treatment (year*treatment) would indicate a response to the experimental treatment during the five years after the removal treatment was enacted. This interaction term was of primary interest as it would suggest that the restoration method (L. maackii removal only) had stimulated a response from the plant community over time that differed from the control plots that still retained L. maackii shrubs. Of course, the intention was to determine if the abundance and species richness of native plants would improve and that exotic plants would not be favored, but this result could not be assured. 


\section{RESULTS}

\section{Herb Community}

Spring herbs

Mean total species richness in spring was 55\% higher in removal than in control plots $(\mathrm{p}=0.008$;

Table 1). Of 68 herb species found this study in spring 2013, 15 were exotic, with any one plot being colonized by at least 2 and by as many as 9 exotic species. In contrast, in any given plot there were between 7 and 27 native species. Both native and exotic species richness were higher in the removal plots than in the control plots (native: $\mathrm{p}=0.008$; exotic: $\mathrm{p}=0.076$; Table 1 ). Herb diversity was higher in removal than in control plots for both Shannon's H' $(p=0.05)$ and Simpson's D ( $p=0.053)$. While the removal plot communities exhibited greater mean evenness as measured by Shannon's Equitability than in control plots, this was not statistically significant ( $\mathrm{p}=0.103$; Table 1 ). Shannon's $\mathrm{H}^{\prime}$ and $\mathbf{J}$ in removal plots declined as the herb cover increased $\left(H^{\prime}: R^{2}=0.760, p=0.01 ; J: R^{2}=0.842, p=0.004 ;\right.$ Fig. $2 A$ and $\left.2 C\right)$. However, species richness in removal plots was not related to percent herb cover $\left(\mathrm{R}^{2}=0.033\right.$, $\mathrm{p}=0.667$; Fig. 2E). Mean spring herb cover in control plots (range: $2.4 \%$ to $38.2 \%$ ) did not significantly differ from removal plots (range: $0.8 \%$ to $36.4 \%)(\mathrm{p}=0.648$; Table 1$)$, despite the fact that average exotic herb cover in removal plots was almost 8 times higher than in control plots $(\mathrm{p}=0.05$; Table 1$)$. Herb cover of native species was not higher in removal plots when compared to controls ( $\mathrm{p}=0.670$; Table 1). In removal plots, there was no significant difference in spring between mean native $(7.75 \pm 3.45 \%)$ and exotic $(10.7 \pm 5.86 \%)$ plant cover $(\mathrm{p}=0.832$; Figure 2A).

The spring herb community in reference plots in 2013 resembled the removal plots, with a few notable distinctions. Average species richness of herbs in the reference plots in the spring was roughly similar to the removal plots $(19.7 \pm 2.4)$. There were approximately two fewer exotic species $(2.33 \pm 0.33)$ and two more native species $(17.3 \pm 2.19)$ than in the removal plots. Shannon's diversity, H', and evenness, $\mathrm{J}$, were both slightly lower in reference plots than they were in removal plots $(1.47 \pm 0.26$ and 
$0.49 \pm 0.07$, respectively). However, Simpson's diversity measure, D, for the reference plots $(2.69 \pm 0.66)$ was 50\% lower than he removal plots, closer to the average measure for the control plots. Average spring herb cover reflected the trends in species richness. Herb cover in the reference plots was approximately similar to removal plots $(17.1 \pm 3.72)$. However, cover by exotic herbs was dramatically lower than in removal plots $(0.30 \pm 0.07)$ while average native cover was almost double that found in removal plots $(16.9$ \pm 3.67 ). (Table 1)

Despite most plots having high herb species richness, just a few species accounted for most of the abundance at the sites, explaining the low diversity index values in these plots. The five most abundant plant species in each control and removal plot in the spring cumulatively accounted for between $67.4 \%$ and $99.9 \%$ of total herb cover in control plots (mean $91.4 \pm 3.9 \%$ ) and between $65.4 \%$ and $99.98 \%$ of herb cover in removal plots (mean $86.22 \pm 4.68 \%$; Appendix 1). These most abundant spring herbs were the exotics Alliaria petiolata (garlic mustard) and Ranunculus ficaria (fig buttercup) and the natives Geum sp., Ageratina altissima (white snakeroot), Carex spp. (several sedges) and Erythronium americana (trout lily) (Appendix 2). There were specific plots where two unusual species were locally abundant and dominant. These were the exotic Lycoris squamigera (Resurrection Lily), which escaped from a residential yard abutting the woodland and the native Camassia scilloides (wood hyacinth) in another site. (Appendix 2).

When compared to the 2008 plant community before treatment, mean spring herb species richness was significantly higher in 2013 than it was in 2008 ( $\mathrm{p}=0.008$ ). While the number of species in removal plots almost tripled from $2008(7.75 \pm 2.3)$ to $2013(21.38 \pm 2.58)$, species in the control plots doubled $(\mathrm{p}=0.013$; Table 2). Spring herb community diversity, H', increased and evenness, J, decreased in removal and control plots between 2008 and 2013 (Table 2), but neither statistically differed between years. While herb cover in the removal plots increased by 2.5 times between 2008 and 2013, the increase was not statistically significant due to high variation in values across plots. Mean herb cover in the control plots decreased over the years, but not statistically (Table 2).

\section{Summer Herbs}

The summer flush of vegetation exhibited some different responses to Lonicera shrub removal than the ephemeral-dominated spring herbs. Mean summer herb richness in removal plots $(17.9 \pm 2.05)$ was 
almost twice that of controls $(9.5 \pm 1.59)(\mathrm{p}=0.017$; Table 1$)$. Native and exotic herb species in removal plots were also approximately twice those in paired controls (exotic: $\mathrm{p}=0.017$; native $\mathrm{p}=0.020$; Table 1 ). Native species richness ranged from 1 to $16($ mean $=8.13 \pm 1.46)$ species in control plots and 8 to $24(15.4$ \pm 2.00 ) in removal plots. Despite higher species richness in the removal plots, there were no significant difference between treatments for any of the summer diversity indices $\left(H^{\prime}: p=0.902 ; D: p=0.524 ; J\right.$ : $\mathrm{p}=0.483$; Table 1 ), indicating that plots were dominated by a few species in any single plot, particularly in the removal plots. This trend was reflected in the significant inverse correlations between summer cover in removal plots and their associated Shannon's H and $\mathrm{J}\left(\mathrm{H}: \mathrm{R}^{2}=0.769, \mathrm{p}=0.010 ; \mathrm{J}: \mathrm{R}^{2}=0.897, \mathrm{p}=0.003\right.$;

Figure 3B and D). Similar to the trend in the spring, herb species richness in summer removal plots was not correlated with herb cover $\left(\mathrm{R}^{2}=0.158, \mathrm{p}=0.377\right.$; Figure $\left.3 \mathrm{~F}\right)$. Mean total herb cover was significantly higher in removal plots than in control plots $(\mathrm{p}=0.024$; Table 1$)$ and ranged from $0.055 \%$ to $6.62 \%$ in control plots and from $1.27 \%$ to $37.9 \%$ in removal plots. This large response in cover in removal plots was dominated by native plants, whose cover was 8 times greater than in control plots $(\mathrm{p}=0.023$; Table 1$)$. On the other hand, exotic plant cover was no higher in removal plots $(0.25 \pm 0.07)$ than in their respective control plots $(0.26 \pm 0.11)(\mathrm{p}=0.328$; Table 1$)$. Overall, native plant cover was 66 times greater than exotic cover in the summer removal plots $(\mathrm{p}=0.022$; Figure $2 \mathrm{~B})$.

The summer herb community in reference plots in 2013 were generally more intermediary between control and removal plot averages. The average herb species richness in reference plots was very similar to the control plot average and lower than in reference plots $(10.7 \pm 0.88)$. This pattern was observed in both the average exotic species richness $(1.0 \pm 0.58)$ and average native species richness $(9.67$ \pm 0.89 ). All three measures of Diversity and Evenness were, on average, lower in reference plots than in either control or removal plots (H’: $1.09 \pm 0.09 ; \mathrm{J}: 0.46 \pm 0.02 ; \mathrm{D}: 2.04 \pm 0.25)$. (Table 1$)$

In the summer, the top five species in the control plots accounted for between $86.1 \%$ and $100 \%$ of the herb cover at their respective sites (mean $93.2 \pm 1.91 \%$; Appendix 1B). In removal plots the top 5 species accounted for $80.6 \%$ to $98.9 \%$ of herb cover (mean $92.3 \pm 1.87 \%$; Appendix 1B). The most abundant herb in any given control plot (which varied from plot to plot) accounted for, on average, $48.2 \pm$ $8.21 \%$ of total cover, ranging from $25 \%$ to $100 \%$ (Appendix 1B). Across all removal plots, the top species 
accounted for up to $56.8 \pm 7.0 \%$ of cover. The exotic, Alliaria petiolata, was found in the top 5 most abundant species in 5 of the control plots and 3 of the removal plots, while the exotic, Duchesnea indica, was in the top 5 most abundant species for one control and one removal plot (but the same paired-plot).

The native, Ageratina altissima was the most abundant and frequently encountered summer herb and was among the top five species in 13 of the 16 experimental plots. The native Phytolacca americana was among the top five in seven plots (both treatment plots at two sites, and the removal plots of 3 other sites), followed by Geum spp. and Asarum canadense, which were among the top 5 most abundant herbs in 5 (both plots in two sites and the control plot of a third site) and 4 (both plots at two sites) experimental plots, respectively. Native sedges of the genus Carex were among the top five herbs in five plots in summer (both plots at one site, two other control plots, and one other removal plot) (Appendix 3).

Only three of the removal plots in the summer had any exotic species among the top five most abundant herbs in that plot (vs. seven of eight removal plots in the spring) and in none of those plots were the exotic the single most abundant herb (vs. four plots in the spring; Appendix 1). Aside from the two dominant herbs in summer, A. altissima and P. americana, no other herb comprised even $0.5 \%$ of cover in any one plot in the summer. The next most abundant eight herbs in the summer are common woodland herbs, including Asarum canadense (wild ginger), Sanicula odorata (clustered blacksnakeroot), Hydrophyllum spp. (waterleaf, likely a mix of $H$. canadense and $H$. appendiculata). Only three species of exotic herbs are present in removal plots in the summer: Alliaria petiolata in three plots, and Arctium minus (lesser burdock) and Duchesnea indica (Indian strawberry) in one plot each (Appendix 3). In contrast, none of the herbs in summer control plots make up more than $0.5 \%$ of cover, even A. altissima, which was still the most abundant herb (Appendix 3). Although, A. canadense and Hydrophyllum spp. were nearly as abundant as in removal plots, $P$. americana's rank dropped to fifth (Appendix 3). Interestingly, despite being fourth most abundant in control plots, A. petiolata had roughly twice the cover as in removal plots (Appendix 3), suggesting that even though this exotic herb can perform better in more open conditions, it may have been outcompeted by other plants in removal plots where light was more available.

Summer herb species richness in control plots nearly doubled from a mean of $5.5 \pm 1.78$ species in 2008 to $9.5 \pm 1.59$ species in 2013 . In removal plots, however, richness nearly tripled from a mean of 5.13 
\pm 1.62 species in 2008 to $17.9 \pm 2.05$ species in 2013 ( $\mathrm{p}=0.011$ for the interaction term of Year*Treatment; Table 2). There was a trend towards a higher herb species diversity, H', in 2013 than was the case in 2008 $(\mathrm{p}=0.09$; Table 2). Shannon's evenness, J, in the summer herb community did not appear to vary by year or treatment (FDR adjusted p-values $>0.1$; Table 2). The herb cover and species richness of summer herbs varied significantly between 2008 and 2013 and across the two honeysuckle treatments. Mean herb cover in the control plots appears to have diminished from $4.93 \% \pm 3.07 \%$ in 2008 to $2.32 \% \pm 0.81 \%$ in 2013 , while in the removal plots cover increased from $1.28 \% \pm 0.68 \%$ in 2008 to $16.74 \% \pm 5.34 \%$ in 2013 ( $\mathrm{p}=0.010$ for the interaction term of Year*Treatment; Table 2).

Average herb cover in the removal plots was explained by the minimum known presence of $L$. maackii at the site; the longer a site had been occupied by L maackii, the more herb cover was measured at that site in 2013. In the summer this may be a function of the canopy cover. The correlation held for both spring and summer herb cover in an exponential model that explained $57.4 \%$ and $58.3 \%$ of the variation in herb cover, respectively ( $\mathrm{p}=0.039$ for both spring and summer; Table 3; Figure 4).

Responses of woody species

Mean seedling density of all woody species combines (pooled seedlings of vines, trees, and shrubs) in 2013 was not statistically higher in removal plots $\left(60,037 \pm 20,648\right.$ seedlings ha $\left.^{-1}\right)$ than in control plots $\left(47,050 \pm 14,202\right.$ seedlings ha ${ }^{-1} ; \mathrm{p}=0.714 ;$ Table 4$)$.

Vines

Ten vine species were found in the experimental plots in 2013, with equal numbers of exotic (Ampelopsis brevipedunculata., Celastrus orbiculatus, Euonymus fortunei, Hedera helix, Lonicera japonica) and native species (Menispermum canadense, Parthenocissus quinquefolia, Smilax sp., Toxicodendron radicans, Vitis spp.). In the summer, there were an average of 1.4 more species of woody vines in the removal plots than in the control plots $(\mathrm{p}=0.05)$, although, neither exotic $(\mathrm{p}=0.113)$ nor native species $(\mathrm{p}=0.521)$ were present in significantly greater numbers in either treatment (Table 5).

However, there was a strong trend of woody vine vegetation in summer 2013 covering more of the ground in removal plots $(11.8 \pm 5.36 \%)$ than it did in control plots $(2.49 \pm 0.987 \%$; $\mathrm{p}=0.053$; Table 6$)$. 
While average exotic vine cover in removal plots $(9.89 \pm 5.49 \%)$ was higher than in control plots $(2.23 \pm$ $0.99 \%)$ the difference was not statistically significant $(\mathrm{p}=0.170)$. There was a strong trend towards greater native vine cover in the removal plots $(1.95 \pm 1.42 \%)$ than in control plots $(0.26 \pm 0.06 \%)$ in the summer $(\mathrm{p}=0.076 ;$ Table 6$)$.

Vines were propagating not only via vegetative growth, but also from germinating seeds. This is evidenced by vine seedling densities in experimental plots ranging between 1,600 ha-1 and 9,800 ha-1, although there was no statistically apparent difference between control and removal plots $(\mathrm{p}=0.30$; Table 4).

The summer woody vine community appears to have responded to both the change in years and to the removal of honeysuckle. Between 2008 and 2013, mean vine cover doubled in the control plots from $1.21 \pm 0.51 \%$ in 2008 to $2.49 \pm 0.99 \%$, but increased ten-fold in the removal plots (Table $2 ; \mathrm{p}=0.057$ for the interaction term Year*Treatment). Species richness for the vines likewise markedly varied between years with significantly higher species richness in 2013 than in 2008 for both treatments (Table 2).

While all three reference plots increased slightly in total vine cover over the five year interval, the variance between the three plots was almost as high as the mean in both $2008(26.6 \pm 22.0 \%)$ and 2013 $(28.7 \pm 23.9 \%)$. Each of the three plots were orders of magnitude apart in terms of absolute cover: one increased from $0.069 \%$ in 2008 to $0.314 \%$ in 2013 another from $9.37 \%$ to $9.59 \%$. The third reference plot may illustrate what can happen if vines are left to grow even after L. maackii is removed: it had cover of $70.3 \%$ in 2008 and $76.3 \%$ in 2013. Two species made up the majority of the cover in that reference plot Euonymus fortunei (73.5\% cover) and Hedera helix (13.9\% cover).

Tree Seedlings and Saplings

Twenty-four tree species were found across all experimental plots in the seedling stratum in 2013 (one seedling of a twenty-fifth species was found in a reference plot), up from twenty in 2008 ( $\mathrm{p}=0.010$ ). In 2013, Fraxinus americana and $F$. pensylvannica accounted for nearly two-thirds of the total tree seedlings $(60.8 \%)$. Seven other species each accounted for $>1 \%$ of tree seedlings, four natives Acer negundo (7.58\%), Celtis occidentalis (5.92\%), Prunus serotina (4.38\%), Acer saccharum (3.06\%); and two 
exotic species: Rhamnus cathartica (9.95\%) and Koelreutaria paniculata (5.38\%). The four exotic species present in the tree seedling stratum (R. cathartica, K. paniculata plus Morus alba and Ailanthus altissima) accounted for $15.5 \%$ of total tree seedlings. In fact, the percentage of exotic tree seedlings declined from 2008 to 2013, despite their appearance in 5 plots where they had not occurred in 2008. Some exotic trees declined in the seedling stratum, while others increased over five years. In 2008, A. altissima seedlings were the most widespread of the exotics, being recorded in both plots at three sites plus one reference plot. By 2013, however, A. altissima seedlings were found in only one control plot. K. paniculata was locally dominant but not widespread, occurring in both plots of one site in both 2008 and 2013. K. paniculata seedlings exhibited a greater than four-fold increase from 75 in 2008 to 313 in 2013. Present in five plots across four sites in 2008, R. cathartica spread dramatically over the five year interval. In 2013, $R$. cathartica seedlings could be found in one or both of the paired plots at every site except one: H6. (Table 7). (Appendix 4)

In 2013, tree seedling densities across all experimental plots ranged between 7,900 $\mathrm{ha}^{-1}$ and $179,100 \mathrm{ha}^{-1}$. Although removal plots on average contained twice the number of tree seedlings than control plots in 2013, the difference was not significant ( $\mathrm{p}=0.255$; Tables 7 and 8). Every experimental plot had more tree seedlings in 2013 than in 2008 ( $\mathrm{p}=0.008)$. There were not more species of tree seedlings in removal plots than there were in control plots in $2013(\mathrm{p}=0.26)$.

A total of 21 species of tree saplings were found in the experimental sites in 2013, up from 10 species in this stratum in 2008. Three additional species of saplings were found only in reference sites: two saplings each of Fagus grandifolia and Juglans nigra and one Quercus sp. There was an average of 3.4 times as many saplings in removal plots as in control plots ( $\mathrm{p}=0.024$; Table 8). As with seedlings, saplings comprised mostly $F$. americana and $F$. pensylvanica across the experimental plots (35.7\%). The native Acer negundo saplings made up 30.6\% of the saplings. Eight other species accounted for the majority of the remaining saplings: six native (Acer saccharum, 7.8\%; Prunus serotina, 7.1\%; Asimina triloba, 5.6\%; Celtis occidentalis, 2.4\%; Aesculus glabra, 1.2\%) and two exotic species (Rhamnus cathartica, 5.6\%; Koelreutaria paniculata, $1.2 \%$ ). The remaining ten species each accounted for $<1 \%$ of 
the saplings. Interestingly, one sapling of the exotic Pyrus calleryana was found, but no other exotic saplings, not even A. altissima. (Appendix 5)

The tree seedling and sapling communities in reference plots in 2013 were generally more similar to the control plots than the removal plots regarding abundance, but more similar to removal plots in species richness. Average species richness of tree seedlings in reference plots $(9.0 \pm 0.58)$ was almost exactly intermediate between control and removal plot averages. However, the average exotic species richness in reference plots $(0.33 \pm 0.33)$ was less than half of the average found in either treatment of the paired plots. The difference in richness was made up in native species richness $(8.67 \pm 0.33)$ which was higher than either of the other treatments. On average, saplings in reference plots $\left(13,600 \pm 9,760 \mathrm{ha}^{-1}\right)$ were about as abundant as in control plots, but only about one quarter the density of saplings in removal plots. Average species richness of saplings in reference plots $(6.33 \pm 2.19)$ appeared higher than that of either treatment in the paired-plots. This is likely due to much lower average exotic species richness $(0.33$ $\pm 0.33)$ and much higher average native species richness $(6.0 \pm 2.0)$ than either control or removal plots. That's about half the number of exotic species in the experimental plots, and three and four times more native species than control and removal plots, respectively. (Table 8)

Tree sapling density appears to have varied between years and across treatments $(\mathrm{p}=0.046$ for the interaction term Year*Treatment). The mean number of saplings per hectare in control plots almost quadrupled from $4.625 \pm 1.79$ in 2008 to $16.63 \pm 6.06$ in 2013 , while removal plots saw an increase from $9.50 \pm 3.60$ per hectare in 2008 to $57.0 \pm 20.1$ saplings per hectare in 2013 . (Table 7 )

Average sapling species richness was $34 \%$ higher in removal than in the control plots in 2013 $(\mathrm{p}=0.05$; Table 8$)$. On average there were two more species of native saplings in the removal plots than in the control plots ( $\mathrm{p}=0.024$; Table 8$)$. No difference between treatments was detected for exotic species of saplings likely due to the small pool of exotic species in that stratum which ranged from none to one in all but one plot which had two species ( $\mathrm{p}=0.456$; Table 8 ). The most widespread species in this stratum were A. negundo and P. serotina, which were found in 10 plots as well as in the reference plots (Appendix 5). Four exotic species were recorded in this stratum. The most prolific of the exotic species was $R$. cathartica, found in five plots across four experimental sites in 2013, increasing from ten saplings in 2008 
to 33 in 2013. K. paniculata was found at only one site in both treatment plots and, while no saplings were noted in 2008, seven were recorded in 2013. One sapling of Morus alba was found in each of two plots (Appendix 5). There was no statistically significant variation when the sapling richness was examined between years or across treatments, nor was there an interaction between main effects ( $\mathrm{p}$-values $>0.1$; Table 7).

Shrubs

Across all experimental plots in $201394.3 \%$ of shrub seedlings were Lonicera maackii with the remainder divided between one exotic species (Ligustrum sinense) and four native species (Lindera benzoin, Staphylea trifolia, Sambucus canadensis, Viburnum dentalis; Appendix 6). Densities ranged between $1,600 \mathrm{ha}^{-1}$ and 14,000 $\mathrm{ha}^{-1}$ with shrub seedling densities an average of 3.5 times greater in control plots than in removal plots, although this was not statistically significant ( $\mathrm{p}=0.428$; Table 4$)$.

It appears that more shrub seedlings, primarily L. maackii, are germinating in the un-cut control plots, but the stem data that follow indicate that they likely do not recruit into the larger size classes. There is a strong trend $(\mathrm{p}=0.075)$ towards higher densities of shrub stems $(\geq 30 \mathrm{~cm}$ tall $)$ in removal plots $(43,938 \pm$ 10,967 stems ha $\left.^{-1}\right)$ than in control plots $\left(23,987 \pm 3,145\right.$ stems ha $\left.^{-1}\right)$. This trend is even stronger when nonLonicera spp. stems are dropped from the test (Removal mean: $34,835 \pm 11,784$ stems ha ${ }^{-1}$; Control mean: $19,588 \pm 2,691$ stems ha $\left.{ }^{-1} ; \mathrm{p}=0.055\right)$. Shrub stems of all species were denser in removal plots than in control plots for those between $30 \mathrm{~cm}$ and $0.99 \mathrm{~m}$ tall $(\mathrm{p}=0.05)$ and for those between $1.0 \mathrm{~m}$ and $1.99 \mathrm{~m}$ tall ( $p=0.056)$. Shrub stems $\geq 2 \mathrm{~m}$ tall were much more common in control plots $(\mathrm{p}=0.003)$, most likely driven by the L. maackii stems that were shorter and uncut in those plots in 2008. (Table 9).

Mean shrub species richness in 2013 did not vary between experimental treatments, either in total $(\mathrm{p}=0.793)$ or when separated into native $(\mathrm{p}=1.00)$ and exotic $(0.447)$ species (Table 5). The second most abundant shrub, another exotic, Ligustrum sinense, spread from 7 plots to 11 plots between 2008 and 2013 (Appendix 6). The native Spicebush, Lindera benzoin, was found in only one of experimental sites in both years, but showed signs of increasing in response to honeysuckle removal after 5 years (Appendix 6). Three other native shrubs (Staphylea trifolia, Sambucus canadensis, and Viburnum dentalis) showed 
similar responses as Lindera: they were found in only one or two plots and the stem density increases where L. maackii had been removed were modest and restricted to their initial plots.

When L. maackii stems are examined by height categories it is evident that shorter, generally younger, stems are driving the trend towards more shrubs stems in removal plots. L. maackii stems accounted for $80 \%$ of the shrub stems $0.3-1.99 \mathrm{~m}$ tall in control plots and $78 \%$ of shrub stems in the removal plots. Mean densities of shorter L. maackii stems $(30 \mathrm{~cm}-0.99 \mathrm{~m})$ were nearly four times greater in removal plots $\left(276.1 \pm 99.7\right.$ stems ha $\left.^{-1}\right)$ than in control plots $\left(70.1 \pm 17.1\right.$ stems ha ${ }^{-1} ; \mathrm{p}=0.061$; Table 9$)$. Although, mean stem densities for L. maackii stems between $1.0 \mathrm{~m}-1.99 \mathrm{~m}$ were about $50 \%$ greater in removal plots than in control plots, this was not statistically significant $(\mathrm{p}=0.160$; Table 9). Predictably, the uncut control plots had more than ten times as many L. maackii stems $>2 \mathrm{~m}$ tall ( $\mathrm{p}=0.003$; Table 9). Despite the removal treatment five years prior, L. maackii stems were found in every plot at each site except one reference site. The total number of $L$. maackii stems $0.3-1.99 \mathrm{~m}$ tall in removal plots $(2,727)$ was triple that found in control plots (894). Six of the eight removal plots had at least one L. maackii stem already two meters tall after five years; three of these plots had 10 or more stems of $L$. maackii plants that had reached $>2 \mathrm{~m}$.

\section{Environmental Variables}

The eight experimental sites had east to northwest-facing aspects. Two sites were southeast- to south-facing, one was east-facing, and the remaining five had aspects in the NW-W-SW arc (Table 10). Two reference plots fell in the same range of aspects, but one was due north (Table 10). Summer herb cover in removal plots in 2013 was positively correlated with the aspect of the dominant slope expressed as degrees from north $(\mathrm{r}=0.649 ; \mathrm{p}=0.082$; Table 11$)$. The dominant slopes at most sites ranged from $12 \%$ to $40 \%$ (Table 10). Slopes at the three reference plots were within a similar range as the experimental sites (Table 10). Soils in all but one experimental plot were silt loam Alfisols with most being in the Crider (Paleudalf) or Caneyville (Hapludalf) series (Table 10, Table 12).

Canopy cover measured using a densiometer ranged between $88.8 \%$ and $99.5 \%$ in 2014 when the attempt was made to minimize influence from shrubs so as to estimate tree cover. Control plots ranged between $96.1 \%$ and $99.5 \%$ cover with an average of $97.2 \pm 0.4 \%$ with removal plots averaging $94.4 \pm$

$0.02 \%$ (Table 3), a difference that was statistically detectable ( $\mathrm{p}=0.015$; Table 13). Summer herb cover was 
negatively correlated with canopy cover $(\mathrm{r}=-0.693 ; \mathrm{p}=0.057$; Table 10$)$. The five removal plots for which LAI was available exhibited values ranging from 1.91 to 6.27 with a mean of $3.67 \pm 0.74$ (Table 3 ).

Leaf litter mass in late spring 2013 did not significantly vary between treatments $(\mathrm{p}=0.237$; Table 13), although there was a trend for removal plots having $28 \%$ less litter mass than control plots (Table 13). However, mass of fine woody debris was three times higher in removal plots than in control plots $(\mathrm{p}=0.05$; Table 13).

Group distinctions: "sun" and "shade" plots

By 2013 it was visually obvious that each of the eight removal plots could be placed into one of two categories of vegetation response, four plots with higher summer herb cover (22.2-37.9\%) and four plots with much lower summer herb cover values (1.27-8.7\%) (Table 3; see also Table 1 and Figure 3B, D, F). Spring herb cover was higher in the plots with a more depauperate community (lower diversity and evenness (Figure 3A, C, E).

Since the plots with the more robust summer herb community also appeared to be the four sunniest sites, these were dubbed "open" and the other four labelled "shade" sites. Sunlight at the forest floor was not measured directly so several proxy measures associated with sunlight at the forest floor were measured to see if they correlated with the visual observation of a sun vs. shade grouping of plots. The distance to forest edge, LAI (for the $\mathrm{N}=5$ sites available), and canopy cover individually exhibited strong negative correlations with summer plant cover in removal plots (Pearson's $r=-0.754,-0.717$, and -0.693 , respectively; $\mathrm{p}=0.142,0.246,0.142$, respectively; Table 11 ). All four of the removal plots with higher plant cover had dominant-slope aspects of southeast to southwest (Table 9), resulting in a positive correlation between south-facing slopes and higher plant cover (Pearson's $r=0.649, p=0.246$; Table 11). Taken together, we concluded that these correlations between summer herb cover and greater light supported a grouping of these plots into "open" vs. "shade" categories for further analyses that attempt to explain the divergent plant community results obtained due to the removal treatment.

When the plant communities in the "open"- and "shade"-plots were compared, only summer herb cover was higher in the "open" plots than in the "shade" plots. Mean summer herb cover in "open" plots 
was $29.8 \pm 3.98 \%$ compared to $3.66 \pm 1.75 \%$ in the "shade" plots $(\mathrm{p}=0.011)$. Herb community diversity, H', and evenness, J, were both lower in "open" plots than in the "shade" plots. Average diversity, H', in "open" plots $(1.00 \pm 0.10)$ was only $60 \%$ of that in control plots $(1.70 \pm 0.15 ; \mathrm{p}=0.044$; Table 14$)$. Average evenness, J, in "open" plots $(0.34 \pm 0.03)$ was just over half of the average for "shade" plots $(0.624 \pm 0.04$; $\mathrm{p}=0.011$; Table 14). Both diversity and evenness in the "shade" plots were about equivalent to the mean control and removal values for summer herbs- only the "open" plot means differed. Summer herb richness and summer exotic herb cover did not significantly vary between "shade" and "open" removal plots (pvalues $>0.6$; Table 14). None of the other woody plant community traits examined varied significantly between "shade" and "open" removal plots in 2013 (p-values >0.6; Table 14). 


\section{DISCUSSION}

Five years after the removal of Lonicera maackii, spring herb communities were richer and more diverse, and summer herb communities more abundant and species rich. Native species numbers were 3 to 6 times greater than exotics in removal plots, which provides optimism that exotic herbs are not yet outcompeting native herbs as these communities recover from decades-long honeysuckle occupancy. However, seasonal and treatment differences in exotic species cover were strikingly apparent in these urban woodlands. In spring, exotic species cover was five times greater in the removal plots than controls, but very low in summer for both treatments. However, only two exotic herbs, A. petiolata and $R$. ficaria more than accounted for the average cover differences between treatments in spring. Summer herb cover within the removal plots varied greatly, however, with half the plots having seven times the cover response of the other half. Supporting evidence is provided showing that the cover differences in summer are likely related to differences in light availability across the plots due to edge proximity and tree canopy density. Species richness differences in control vs. removal plots in summer may also be related not only to differences in light but also to increased entry of seed via wind and potentially animal vectors that correlate with greater understory openness due to shrub removal.

\section{Herbs}

This study found evidence that the release from competition for light may be the most important driver of the resultant plant communities. That is because distinct responses to shrub removal were detected between spring and summer herb communities with the contrast in herb abundance between removal and control plots being greater in summer when tree canopies were expanded than in the spring before leaf-out, which would result in less light contrast between control and removal plots. Also, in plots where L. maackii had been removed, the summer herb community could be differentiated into two groups based on relative proximity to edges and to canopy cover, both of which affect light availability. 
The increase in exotic cover in spring may demonstrate that light had been a potential limiting factor for introduced as well as native species that had been otherwise suppressed by the early emergent $L$. maackii. The timing of emergence by invasive exotic species can have a strong effect on their relative success against native herbs (Rejmanek 2013; Wainwright and Cleland 2013; Cleland et al.2013). The most prolific herb in the spring of 2013 was the exotic invasive, Alliaria petiolata (garlic mustard). A biennial which can bolt in the second year of growth to form stands up to $120 \mathrm{~cm}$ tall, A. petiolata is considered shade tolerant (Miller 2004), but was much more prominent in plots that lacked L. maackii (Appendices 2 and 3). Englehard and Anderson (2011) found evidence suggesting that A. petiolata's invasive success is linked to the availability of resources such as sunlight in this early phase of the growth season. Boyce (2015), in a similar study in southwest Ohio, found results similar to those in this study, but suggested that A. petiolata's success may be "transitory". However, after five years garlic mustard was still an important component of the spring herb understory in Cherokee Park woodlands. Likewise, the exotic Ranunculus ficaria, was also more abundant in the removal than in the control plots $(2.1 \%$ mean cover in removal plots vs. $0.06 \%$ mean cover in control plots). Considered an early emergent herb, it is possible that $R$. ficaria is also well positioned to take advantage of greater light once shrub cover is removed (Masters 2014; Masters and Emery 2016). Why native spring ephemerals did not respond with a greater cover response under the same circumstances as these particular exotics may be related to potential contrasting means of dispersal and potentially low abundance in the seed bank. However, despite a subdued cover-abundance response by native spring species within the 5-year period, the species richness of natives did increase more in the removal than in control plots, providing optimism in their fuller recovery and spread over time.

As expected, the summer herb community species richness and abundance increased over five years, with removal plots showing large increases compared to control plots, particularly in those sites closer to edges and with lower tree canopy cover. This again implicates light as a main factor predicting the extent of the community cover response, and also community species composition. Five years after $L$. maackii removal, most of the plots were dominated by Ageratina altissima and Phytolacca americana. These species are common in disturbed woodlands containing canopy gaps, and also in thin woods (Campbell and Medley 2012) and along woodland edges where more light is available. There is evidence 
that $A$. altissima may be "adapted to allow opportunistic germination" in precisely the late spring and early summer season that corresponds with our data collection and is considered "disturbance dependent" in a forest context (Redwood et al. 2016). P. americana, too, seems to be well adapted to take advantage of germinating conditions in forest gaps particularly the increased availability of light (Hyatt and Casper 2000).

The fact that native herb cover in the summer communities was greater than exotic cover provides encouragement for achieving management goals of restoring native herbs to these woodland understories. There was an average of one additional exotic species in the removal plots, suggesting that they not only are present within dispersal distance, but are also capable of taking advantage of the removal of L. maackii. Encouragingly, however, in those removal plots there were an average of seven additional native species (two more than in the spring community). While there were numerous native species in the top five most abundant herbs in control and removal plots, several of the most abundant native herbs in the control plots were populations localized to only one or two sites (ex. Trillium flexipes and Cammassia scilloides in spring and Laportea canadensis and Collinsonia canadensis in summer; Appendices $2 \& 3$ ). This suggests that simply removing L. maackii may not be sufficient to expect a widespread increase in native plants with limited dispersal mechanisms. The native herbs with the most dramatic increases $(A$. altissima and $P$. americana) are "weedier" species that one would expect to respond well to sudden openings in the subcanopy. Whether this flush of growth might alter the ultimate successional pathway of the sites (i.e. alter the composition of the canopy community or of the ultimate stable forest floor community) would require continued long-term monitoring.

In general, the findings for the herb community support those of previous studies that used smaller plot sizes than those in this study and examined species colonization over fewer growing seasons (Gould and Gorchov 2000; Collier et al. 2002; Gorchov and Trisel 2003; Owen et al. 2005; Swab et al. 2008). A removal-response study in northern Kentucky that subsampled larger plots, and reported data through eight growing-seasons after L. maackii removal found similar trends for herb-layer plants- particularly the increase in late-spring- and summer-blooming plants (Boyce 2015). Both overall species richness and herbaceous cover increased, although cover had a lag time of about two to three years depending on 
intensity of initial L. maackii invasion. That same study found data suggesting that exotic species richness increased, but decreased as proportion of herb cover. Of the 14 species listed by Boyce (2015) with $\geq 5 \%$ mean cover in at least one year of the study, five were among the most abundant species found in this Cherokee Park study. The two most common, A. altissima and A. petiolata, were listed in all four categories of L. maackii canopy density (light, moderate, heavy, very heavy). The sedge Carex jamesii and the forb Polygonatum biflorum both have high coefficients of conservatism (hereafter "CC"; Appendix 2). The CC is a rating between 0-10 that rates the relative fidelity (or conservatism) of any given species in association with the other species native to the region or geographic area. A higher CC indicates a higher confidence that the species is from a remnant native community rather than degraded or anthropogenically disturbed habitats as indicated by lower CCs (Shea et al. unpublished, sensu Swink and Wilhelm 1994). The fifth herb that was abundant in both studies, Geum vernum, was not distinguished from G. canadense in the spring of this study and was pooled as Geum spp. (Appendix 2). Boyce (2015) also noted as abundant two species that were present in our study, although in lower abundances: Stellaria media and Galium aparine. Noticeably absent from Boyce's (2015) list of abundant herbs was P. americana, one of the most abundant summer herbs in this study.

\section{Woody plants}

Based on this study, there is evidence for cautious optimism for the recovery of native woody species after shrub honeysuckle removal. Five years after L. maackii removal, tree, vine and shrub seedling density responses increased, but were not statistically greater in the removal than in the control plots (Table 7). Only tree sapling density was statistically detected to have been positively affected by the removal of $L$. maackii in this study, with increased sapling densities across both treatments over time, but a greater increase in the removal plots. A recent study in southwest Ohio found that larger stems of L. maackii were associated with suppressed Acer saccharum seedling recruitment, but those same stems may protect young trees leading to greater recruitment of saplings (Cameron et al.2016). However, L. maackii has been noted to have differential impacts on canopy tree species survival on a species-by-species basis (Hartman and McCarthy 2004). 
It is very possible that the increases in woody seedlings and saplings over time in both control and removal plots can be explained by the ongoing honeysuckle and vine removals that occurred across the entire park woodlands over this period. In 2008, the treatment sites were surrounded by a woodland matrix dominated by L. maackii. By 2013, almost all L. maackii shrubs and invasive vine shrouds on trees had been removed, allowing greater growth and reproduction by trees and other woody plants throughout the park. The five-meter wide honeysuckle buffer left around the control and removal plot-pairs may not have been as effective in blocking light and mediating other abiotic factors like wind. This likely resulted in greater seed production in the external woodlands as well as increased entry into both the control and removal plots. Therefore, the environmental contrast in removal vs. control plots would have been lower in 2013 than in 2009 right after shrub honeysuckle removal. This potential explanation for the woody seedling and sapling changes over time is supported by a concurrent study (Moore et al. unpublished) in Cherokee Park that found a 14-fold increase in tree seedling densities and a tripling of sapling densities that occurred over the same time-frame as this study in thirteen permanent $500 \mathrm{~m}^{2}$ plots. By covering a larger proportion of the park, Moore et al. (unpublished) provided a clearer snapshot of forest tree community change from 2008 and 2013 than our smaller-scale plots, which exhibited much greater plot-to-plot variability in woody seedling and tree sapling densities.

With one exception (Rhamnus cathartica), threats to native tree establishment from invasive exotic trees remained low in these woodlands after honeysuckle shrub removal. Of the six species of invasive exotic trees found in this study, Ailanthus altissima was not found in large numbers in the seedling layer ( $0.17 \%$ of seedlings), and seedlings and saplings of Koelreuteria paniculata were localized to a single plot pair. Neither of these species was reported by Moore et al. (unpublished). While small saplings of Ailanthus altissima were observed in a few plots in 2008, by 2013 these same individual saplings had died due to extensive herbivory by caterpillars of the Ailanthus webworm moth (Atteva aurea) over several consecutive years (M. Carreiro pers. comm.). Koelreuteria paniculata occurs in a restricted area and any threats from this tree species can be easily dealt with by cutting down the few adult trees there. On the other hand, Rhamnus cathartica, a subcanopy tree, became more widespread and abundant in our plots after honeysuckle removal. This tree, which was present in all sites, was the second most abundant seedling found, accounting for $9.95 \%$ of all tree seedlings. This small understory tree has displayed 
numerous traits that contribute to its success as an invasive exotic in Eastern North America and has a variety of known or suspected impacts on native ecosystems (Knight et al. 2007). The rapid response to honeysuckle removal by this sub-canopy tree may threaten the recovery of the native plant community since it appears to be taking over the niche space once held by L. maackii in this woodland. Management must deal with removal of this species as quickly as possible if gains in native plant community restoration from honeysuckle removal are to be secured.

The success of native trees, however, can also be threatened by invasive pests. Among the most widespread and abundant tree seedlings (60.8\% of all tree seedlings in 2013) in our plots were Fraxinus spp, primarily $F$. americana and $F$. pennsylvanica. This high proportion of Fraxinus spp. seedlings is of particular concern to the restoration of these park woodlands given the recent detection in 2009 and spread of the Emerald Ash Borer in Kentucky (https://entomology.ca.uky.edu/ef453). Moore et al. (unpublished) found a dramatic decrease in Fraxinus spp. seedlings between 2008 and 2013 (from $7.4 \%$ to $2.7 \%$ of all surveyed seedlings, respectively). This is likely due to the death of mature reproductive trees, which was first observed in the park in 2011 and the short longevity of ash in the seed bank (Hille Ris Lambers et al. 2005; but see also Burns and Honkala 1990). Unfortunately, some eradication methods for the control of the Emerald Ash Borer can result in the spread of other invasive plants, including Lonicera spp. (Hausman et al. 2010).

In contrast with exotic trees, some of the vines found to be recovering in these plots are a threat to forest regeneration, as they may decrease tree seedling germination, strangle saplings and over-top the canopy of mature trees (Webster et al. 2006). While the exotic vines, Ampelopsis brevipedunculata and Celastrus orbiculatus, were found in small numbers inside the plots, they are important invaders along forest edges in Cherokee Park, forming complexes of vines growing up into the upper forest canopy and overtopping shrubs and small trees (M. Waltman, pers. comm.). They may also get a foothold inside woodland fragments after tree canopy gaps form, such as those expected in greater numbers as mature ash trees die in Cherokee Park. Seedling densities and ground-level foliar cover ( $<30 \mathrm{~cm}$ high $)$ of $A$. brevipedunculata were higher in the removal plots, especially those closer to road edges and having lower canopy cover, and therefore could pose an immediate threat to tree seedlings and saplings growing in these 
plots. Two other exotic low-growing vines found in this study, known to be shade tolerant, Hedera helix and Lonicera japonica, have been found to exclude seedlings of native trees and shrubs in other forests (Vidra et al. 2006). However, Euonymus fortunei is likely the vine of most concern to restoration efforts of both woody and herbaceous communities in Cherokee Park. In the removal plots, E. fortunei foliar cover increased nearly 50-fold between 2008 achieving mean coverage of $72.1 \%$, becoming the most abundant vine found in this study. Of all the vines found in this woodland, this shade-tolerant vine has benefited the most from honeysuckle removal, since Moore (2015) also found to have increased across the entire park between 2007 and 2014. The success of E. fortunei is of great management concern, because it has the potential to suppress the recruitment and growth of many other plants including trees, via several mechanisms including light reduction for seed germination, alteration of soil conditions and strangling young saplings (Smith and Reynolds 2012).

\section{The Return of Honeysuckle}

One issue of management concern is determining how quickly L. maackii may recolonize an area after removal, and therefore how often to return to an area to remove it again. The only clear consensus based on other studies that followed L. maackii recruitment post-removal is that L. maackii can reinvade after removal. In southwest Ohio, Boyce (2015) found L. maackii seedling densities similar to those in this study, but did not mention post-seedling stem recruitment. A study in north-central Tennessee focused on densities of L. maackii stems >1m after recovery periods of 1-7 years, but found densities roughly onethird of those found in this study (Loeb et al. 2010). Runkle et al. (2007) found stems $\geq 2 \mathrm{~m}$ in $22 \%$ of 180 $1 \mathrm{~m}^{2}$ removal plots after 8 years, but did not note the number of stems.

In the absence of further management efforts it is clear that L. maackii is re-invading where it has been removed in Cherokee Park. In 2013, L. maackii stems (> 30cm) were found in every plot. Since regrowth from cut-stumps painted with Roundup was observed in only one instance, these individuals could have entered as seed or grown from very small plants that had not been removed in 2009. In addition, due to park-wide removals of this shrub light conditions, wind penetration, and animal entry patterns likely changed in ways that would have promoted honeysuckle colonization and growth for both control and removal plots. 
Higher connectivity of forest patches is associated with higher L. maackii distribution (Hutchinson and Vankat 1998), suggesting that seed dispersal vectors are selective for forest canopy, as opposed to open spaces and land under agricultural use. However, the colonization of new habitats by L. maackii appears to follow the edges of woodlands (Hutchinson and Vankat 1997 \& 1998), edges that abound in the fragmented matrix of forest, flood-plain meadows, roads, and residential yards in and around urban parks like Cherokee Park. This suggests that urban parks are particularly vulnerable to re-invasion even after removal of populations in the park woodlands.

Important sources of L. maackii seed into these woodlands are the many privately owned yards adjacent to the park where this ornamental plant continues to grow, particularly along property boundaries that owners manage less often. The abundance of L. maackii in these properties is, therefore, a great concern to woodland managers working to maintain a high quality native community in the forested areas of Cherokee Park since they represent seed sources that can attract animal vectors that can subsequently enter the woodlands. The removal of this shrub in the woodlands and the simultaneous alterations in forest physical structure may also actually compound this threat by increasing L. maackii seed entry via animal, especially bird, vectors entering from these boundaries. Bartuszevige and Gorchov (2006) found that viable seeds passed through the guts of American Robins (Turdus migratorius). These birds are likely attracted to L. maackii fruit along the shared park-private yard boundaries, then fly into the woodlands where they later evacuate seeds. This potential is supported by Lynch (2016), who found that higher numbers of T. migratorius were attracted to dense stands of L. maackii in the fall when fruit was ripening as compared to other seasons of the year.

While it is possible that the proximity of seed sources (control plots, un-restored park woodlands, shrubs adjacent to the park) could increase the propagule pressure in newly opened woodlands after the removal of L. maackii, Hutchinson and Vankat (1997) found that higher light levels (in addition to proximity to potential seed sources) are key to predicting the invasibility of a forest to L. maackii. Loeb et al. (2010) found evidence that annual management efforts across several years are much more effective at controlling the number of L. maackii stems $>1 \mathrm{~m}$, than a single management event. In fact, the increased light caused by the removal of L. maackii may release any L. maackii plants that escaped removal from 
conspecific competition for light. L. maackii can better take advantage of light in sunnier habitats than native competitors (Luken et al. 1997b). Additionally, L. maackii have higher photosynthetic rates and correspondingly higher biomass in sunnier habitats and even produce more fruit in open and edge habitats than they do in forest interiors (Lieurance and Landsbergen 2016). This suggests that the newly-opened woodlands may be high quality habitat for re-invasion.

Given the increase in Lonicera spp. seedling densities (Table 7) and the distribution of stems (Table 9) within 5 years of shrub removal, it is apparent that Lonicera is not only arriving, but is establishing itself once again in the plots where it was removed and within five to seven years can become reproductive (Deering and Vankat 1999).

\section{Plant Community Development and Light Availability}

The responses and successional direction of forest plant communities after disturbances caused by tree death (i.e. gap formation) can be affected by light levels (Kupfer and Runkle 1996). In this study, it was evident that a large contrast existed in summer herb cover among the removal plots and that this cover contrast appeared to be related to the amount of light entering the plots. This prompted the placement of removal plots into two groups, termed "open" vs. "shaded" plots, for further analysis of the plant communities that had developed therein. Support was provided for this light hypothesis and grouping by acquiring data on removal plot proximity to forest edges created by roads and meadows, aspect, and tree cover (densiometer readings and LAI). The strongest correlate with summer herb cover across the removal plots was edge proximity, followed by tree LAI. By comparing community diversity and species composition in these two groups of removal plots ("open" vs. "shaded") over time, the roles of edge proximity and light in influencing plant community responses to honeysuckle shrub removal in urban woodlands over time can be better understood.

Light is an important resource in a forest ecosystem with multiple canopy layers. Invasive plants, especially shrubs like L. maackii, can often spread along forest edges (Hutchinson and Vankat 1998) decreasing in frequency and establishment rates as the distance from the edge increases. This is presumed to be related to decreasing light availability at the forest floor (Flory and Clay 2006, Flory and Clay 2009b). In an intact canopy, while light from treefall gaps can be important for the establishment of invasive plants, 
propagule rain and species-specific life-history traits are also important (Driscoll et al. 2016). Light availability under a forest canopy impact the establishment of grasses in Indiana woodlands (Flory et al. 2007) and can even reverse the relative success of native versus exotic shrub and understory tree seedling survival (Flory and Clay 2009a).

After five growing seasons, the herb communities that developed in the "shaded" removal plots were comprised of species often listed as native components of eastern deciduous forests (Natural Resources Conservation Service 2016). These were Asarum canadense (wild ginger), Hydrophyllum spp (two species of waterleaf), Sanicula odorata, Arisaema triphyllum, Polygonatum biflorum, Hypericum punctatum, Stellaria pubera, and Collinsonia Canadensis, which all together accounted for $2.05 \%$ cover (Appendix 3). These eight species also tend to be lower growing $(<0.5 \mathrm{~m})$, forest floor species. In contrast, summer herb cover in the "open" removal plots was 7 times greater the "shaded" removal plots. While $A$. altissima and P. americana, indicative of disturbed and more open woodlands, were present in shaded plots, they were smaller individuals. These two species dominated the summer herb communities in "open" removal plots (A. altissima (18.8\% cover), P. americana ( $7.45 \%$ cover)). In one plot “open" plot Verbesina alternifolia was locally abundant accounting for $0.41 \%$ of cover in the "open" plots. Solidago canadensis and Oxalis stricta were the next most abundant summer herbs in open plots $(0.325 \%$ and $0.321 \%$ cover, respectively). Increased summer herb cover was correlated with reductions in community diversity, H', and evenness, J, in removal plots (Figure 3B, D). It is likely that increased biomass by upright, fast-growing herbs such as P. americana, V. alternifolia and A. altissima shaded out other herbs, resulting in lower $\mathrm{H}^{\prime}$ and $\mathrm{J}$ in those sunnier sites where they dominated. The fact that species richness did not vary with cover (Figure 3F) demonstrates that the other herb species were able to grow from the seed bank and arrive in the more open removal plots, but did not flourish under the conditions found there. There were three species, accounting for just $0.738 \%$ cover, found only in "open" removal plots. These were Eupatorium serotinum, Arctium minus, and Symphyotrichum lateriflorum the seventh, eighth, and tenth most abundant herbs in these "open" plots (A. minus is an exotic). All three of these species along with A. altissima and $V$. alternifolia are members of the Asteraceae family having wind-dispersed seeds. (Appendix 7). 
In addition to light, the structure of a forest (both understory and canopy) may play a part in determining the community assemblage. The removal of dense edge vegetation, as often happens during $L$. maackii and vine removals during woodland restoration efforts, can increase the flow of seeds into the woodland interior (Cadenasso and Pickett 2001). Wind-dispersed species, such as members of the Asteraceae, would be expected to benefit the most from this alteration in the forest structure (Cadenasso and Pickett 2001) and might explain the relatively high abundance of certain herbs species in the removal plots, especially Ageratina altissima and the four other most abundant species found only in the "open" plots. The maintenance of dense foliage at the edge of a forest may provide some buffer against exotic species invasion into the interior (Brothers and Spingarn 1992), but may also filter out other wind-dispersed native herbs. The shade provided by a more closed canopy may also differentially affect species growth by altering moisture regimes via buffering temperature and reducing evaporation rates. There is some evidence linking a more open forest canopy (and mesic soil moisture levels) to higher proportions of herbaceous seeds in forest seed banks- compared to more closed canopies where seeds of woody species predominated in the seedbanks (Leckie et al. 2000). Leckie et al (2000) posited that this distinction in seedbank communities was more due to seed dispersal and dormancy characteristics of species native to the old growth forest of their study (rather than inputs from the surrounding agricultural-dominated landscape). This suggests that the capacity for divergent communities may be present in an ecosystem. There are many factors that determine which seeds enter, survive and germinate in a site, all of which could change as plant community development progresses in these fragmented urban woodlands.

\section{Other Factors may Affect Community Development}

Direct competition for light may only be a partial explanation for lower herb abundance under $L$. maackii. Smith (2013) suggests that in many studies which implicate direct competition for light based on an observed extended leaf phenology may be overlooking other mechanisms of displacement such as altered soil nutrient cycling, allelopathy, and modifying the behavior of herbivores and pollinators. However, removal of this shrub may not alter all of these factors immediately, thereby leaving legacies that could have long-lasting effects on plant community development that this study was not designed to address. 
This study, designed to test the efficacy of restoration practices, did not explicitly examine these alternate mechanisms. However, we may have found some indirect evidence supporting at least one apparent competitive interaction. A major component of the summer herb community in the more open plots, Phytolacca americana, was found almost exclusively in the gaps formed from the removal of $L$. maackii in another study in Northern Kentucky (Luken et al. 1997b). Being primarily bird-dispersed it was not surprising to find the native herb P. americana in many of our plots. The abundant populations found in the more open, sunnier, sites may be explained by $P$. americana being more limited by seed predation than by dispersal (Orrock et al.2006). Seed predators have been shown to be preferentially more active and use L. maackii thickets for cover from their own predators given the right conditions (Meiners 2007; Mattos and Orrock 2010; Dutra et al. 2011). For instance, Dutra et al. (2011) linked the usage of L. maackii cover by nocturnal rodent seed predators to cloudless nights, indicating a need for protection from moonlight to escape sight-predators. By removing the protective shrub canopy, seed predation by small rodents may have been reduced allowing for the abundant stands of $P$. americana observed in the sunnier "open" plots. It is possible that plots with less tree-canopy cover would allow even more moonlight to reach the forest floor further reducing rodent seed predation activity even further in plots where L. maackii had been removed.

The release from nocturnal seed predation may help account for localized densities of Fraxinus spp. seedlings found in a few of our removal plots [see above]. Meiners (2007) used Fraxinus pennsylvanica seeds in their study and found $74 \%$ of seeds removed at the end of the 28 -day study. This suggests that in areas where L. maackii cover is removed, if there is a reduction of seed predation by rodents, there may be a concomitant increase in seed survival to germination and seedling status that more light promotes. Proximity to adult Fraxinus seed sources would be expected to account for a majority of seedling density, but the reduction in seed predation could be a contributing factor to increased seedling recruitment.

In addition to seed predation, herbivory may also play a role in reducing the survival of some native herbs, particularly in the removal plots where plant growth was greater. White-tailed Deer (Odocoileus virginianus) have been observed in Cherokee Park, in areas immediately adjacent to the study 
sites (E. Levine, personal observation). Intense browsing by deer is known to have dramatic negative impacts on the abundance and survivorship of the understory plant community of forests (Russel et al. 2001; Rooney 2001; Ruhren and Handel 2003). In addition to deer, heavy clipping of smaller herbs by animals (likely rabbits) has been observed in the removal plots (M. Carreiro, pers. comm.). It is possible that any preferentially browsed smaller herbs that were present in the plots might have left higher proportions of $P$. americana and A. altissima, both of which are known to contain herbivory-reducing phytotoxins. Such preferential browsing could reduce the richness and evenness of the plots while still allowing for large biomass accumulation of the dominant herbs.

\section{Duration of Invasion}

In addition to altering the specific communities of the different plant strata (spring and summer herbs and woody plants), the duration of invasion leave a discernable legacy effect on the forest as a whole. Forest sites with invasion durations of 18-26 years have been shown to have lower densities of herb, seedling, and sapling layers and reduced seed bank species richness than non-invaded forests (Hartman and McCarthy 2008). Duration and intensity of invasion by L. maackii can lead to suppressed tree basal area in forests (Hartman and McCarthy 2007). In this Cherokee Park study the length of time that a site has been known to be invaded by L. maackii correlated positively with summer herb cover. In sunnier more "open" sites (Figure 4) ring counts of the largest shrubs removed indicated that the site had been colonized for at least 17 to 22 years, whereas in the "shaded" removal plots the sites had been colonized for 24 to 31 years . The relative openness of these plots can therefore be explained by duration of seedling and sapling recruitment suppression and suppression of canopy tree growth over decades by L. maackii. These potentially long-term legacy effects of $L$. maackii invasion underscore the importance of responding to invasion before it has a chance to alter the long-term structure of the forest. If L. maackii reduces tree canopy density by suppressing regeneration, then the resulting plant communities that develop after shrub removal in forests will likely resemble those of our "open" plots rather than the "shade" plots: dominated by relatively few herbs with reduced diversity and abundance of other herbs which might be more desirable for management goals.

\section{Conclusions}


The herbaceous plant community on the forest floor where L. maackii has been removed shows signs of release from competition with $L$. maackii, however the resulting communities may be distinct from one another based on the availability of light penetrating the summer tree canopy. Distinctions in summer herb cover and community diversity and structure were observed and herbs of greater value to conservation were less important components of the summer herb communities in sunnier locations. The sunnier locations were correlated with longer durations of L. maackii invasion, suggesting that suppression of canopy regeneration by L. maackii might have left a legacy in the forest community structure resulting in less desirable herb communities even five years after the removal of the invasive shrub.

Woody plants are also taking advantage of what appears to be a release from competition with $L$. maackii with increases in seedling densities, species richness, vine cover, and sapling abundance. The increase in cover by invasive exotic vines should concern managers and indicate a need for comprehensive and continued removal efforts. Compared to the broad research available on L. maackii there is relatively little research on the specific effects of the exotic vines found in this study (E. fortunei, Ampelopsis brevipedunculata, Hedera helix). Also of concern is the species composition of the trees that are regenerating. Very few oak seedlings or saplings were observed, while Acer saccharum and Fraxinus spp. were most abundant. Both trees are common in many parts of the park, but the Emerald Ash Borer has been devastating the Fraxinus spp. canopy in the region.

Of greatest concern, perhaps, is the return of L. maackii. Few studies explicitly examine the recolonization by the shrub once removal has been performed. Even leaving a relatively small patch of reproductively mature $L$. maackii might greatly increase the chance of re-invasion. Given the widespread sources of seeds in the urban residential landscape and the potentials for dispersal vectors by birds and deer reintroduction seems likely, with re-establishment to follow unless vigilance is maintained. In order to minimize re-invasion removal efforts should be careful not to leave any seed sources within the woodlot and restoration should be combined with plantings to maintain a dense canopy and restore the integrity of the forest edge as a buffer against some seed vectors.

Natural areas managers need to be aware of and account for the abiotic factors-especially sunlightthat influence invasion and re-invasion and that guide succession after the removal of an invasion. This 
awareness is especially important as differing restoration methods can affect the resulting plant community (Flory and Clay 2009a; Loeb et al. 2010). There is evidence that colonization windows can close after -5years of succession in old-field settings and that it is linked to the closing of a canopy of perennial species (Bartha et al. 2003). If a similar window can be determined for the type of secondary succession examined in this study it may guide land managers in planning restoration time-lines and to minimize reintroduction of invasives and preserve desired native communities. 


\section{REFERENCES}

Arthur, M., S. Bray, C. Kuchle and R. McEwan (2012). "The influence of the invasive shrub, Lonicera maackii, on leaf decomposition and microbial community dynamics." Plant Ecology 213(10): 1571-1582.

Baker, A. and B. Murray (2010). "Relationships between leaf-litter traits and the emergence and early growth of invasive Pinus radiata seedlings." Weed Research 50(6): 586-596.

Bartha, S., S. J. Meiners, S. T. Pickett and M. L. Cadenasso (2003). "Plant colonization windows in a mesic old field succession." Applied Vegetation Science 6(2): 205-212.

Bartuszevige, A. M. and D. L. Gorchov (2006). "Avian seed dispersal of an invasive shrub." Biological Invasions 8(5): 1013-1022.

Blair, B. C. and A. Stowasser (2010). "Impact of Lonicera maackii on decomposition rates of native leaf litter in a southwestern Ohio woodland." Ohio Journal of Science 109(3): 43.

Borgmann, K. L. and A. D. Rodewald (2005). "Forest restoration in urbanizing landscapes: interactions between land uses and exotic shrubs." Restoration Ecology 13(2): 334-340.

Boyce, R. L. (2015). "Recovery of native plant communities in southwest Ohio after Lonicera maackii removal 1." Journal of the Torrey Botanical Society 142(3): 193-204.

Brothers, T. S. and A. Spingarn (1992). "Forest fragmentation and alien plant invasion of central Indiana old-growth forests." Conservation Biology 6(1): 91-100.

Bruner, A. G., R. E. Gullison, R. E. Rice and G. A. Da Fonseca (2001). "Effectiveness of parks in protecting tropical biodiversity." Science 291(5501): 125-128.

Burns, R. and B. Honkala (1990). "Silvics of North America, Vol. 2-Hardwoods, Agricultural Handbook 654." Forest Service, Unites States Department of Agriculture, Washington, DC.

Cadenasso, M. L. and S. T. Pickett (2001). "Effect of edge structure on the flux of species into forest interiors." Conservation Biology 15(1): 91-97.

Callaway, R. M. and J. L. Maron (2006). "What have exotic plant invasions taught us over the past 20 years?" Trends in Ecology \& Evolution 21(7): 369-374.

Cameron, G. N., T. M. Culley, S. E. Kolbe, A. I. Miller and S. F. Matter (2016). "Relationships between an invasive shrub Amur honeysuckle (Lonicera maackii, Caprifoliaceae) and environmental factors on recruitment of sugar maple trees (Acer saccharum, Aceraceae) in southwestern Ohio 1, 2." The Journal of the Torrey Botanical Society 143(4): 386-397.

Campbell, J. and M. Medley (2012). "The atlas of vascular plants in Kentucky." Current draft posted at http://bluegrasswoodland. com.

Carreiro, M. M. and W. C. Zipperer (2011). "Co-adapting societal and ecological interactions following large disturbances in urban park woodlands." Austral Ecology 36(8): 904-915. 
Cipollini, D. and M. Dorning (2008). "Direct and Indirect Effects of Conditioned Soils and Tissue Extracts of the Invasive Shrub, Lonicera Maackii, on Target Plant Performance." Castanea 73(3): 166-176.

Cipollini, D., R. Stevenson and K. Cipollini (2008). "Contrasting effects of allelochemicals from two invasive plants on the performance of a nonmycorrhizal plant." International Journal of Plant Sciences 169(3): 371-375.

Cipollini, K. and M. Greenawalt Bohrer (2016). "Comparison of allelopathic effects of five invasive species on two native species 1." The Journal of the Torrey Botanical Society 143(4): 427-436.

Cipollini, K. A., G. Y. McClain and D. Cipollini (2009). "Separating Above- and Belowground Effects of Alliaria Petiolata and Lonicera Maackii on The Performance of Impatiens Capensis." The American Midland Naturalist 160(1): 117-128.

Cleland, E. E., L. Larios and K. N. Suding (2013). "Strengthening invasion filters to reassemble native plant communities: soil resources and phenological overlap." Restoration Ecology 21(3): 390-398.

Clinton, W. J. (2005). "Executive Order 13112 of February 3, 1999, on Invasive Species " Federal Register 64 no. 25.

Cole, D. N. and P. B. Landres (1996). "Threats to wilderness ecosystems: impacts and research needs." Ecological applications 6(1): 168-184.

Collier, M. H., J. L. Vankat and M. R. Hughes (2002). "Diminished Plant Richness and Abundance below Lonicera Maackii, an Invasive Shrub." American Midland Naturalist 147(1): 60-71.

Czarapata, E. J. (2005). Invasive plants of the upper Midwest: an illustrated guide to their identification and control, Univ of Wisconsin Press.

D'Antonio, C. and L. A. Meyerson (2002). "Exotic plant species as problems and solutions in ecological restoration: a synthesis." Restoration Ecology 10(4): 703-713.

D'Antonio, C. M. and P. M. Vitousek (1992). "Biological Invasions by Exotic Grasses, the Grass/Fire Cycle, and Global Change." Annual Review of Ecology and Systematics 23(ArticleType: primary_article / Full publication date: 1992 / Copyright (c) 1992 Annual Reviews): 63-87.

Davis, M. A., J. P. Grime and K. Thompson (2000). "Fluctuating Resources in Plant Communities: A General Theory of Invasibility." Journal of Ecology 88(3): 528-534.

Deering, R. H. and J. L. Vankat (1999). "Forest Colonization and Developmental Growth of the Invasive Shrub Lonicera maackii." American Midland Naturalist 141(1): 43-50.

Dorning, M. and D. Cipollini (2006). "Leaf and root extracts of the invasive shrub, Lonicera maackii , inhibit seed germination of three herbs with no autotoxic effects." Plant Ecology 184(2): 287-296.

Driscoll, A. G., N. F. Angeli, D. L. Gorchov, Z. Jiang, J. Zhang and C. Freeman (2016). "The effect of treefall gaps on the spatial distribution of three invasive plants in a mature upland forest in Maryland 1,2." The Journal of the Torrey Botanical Society 143(4): 349-358.

Dutra, H. P., K. Barnett, J. R. Reinhardt, R. J. Marquis and J. L. Orrock (2011). "Invasive plant species alters consumer behavior by providing refuge from predation." Oecologia 166(3): 649-657.

Ehrenfeld, J. G. (2003). "Effects of exotic plant invasions on soil nutrient cycling processes." Ecosystems 6(6): 503-523.

Engelhardt, M. J. and R. C. Anderson (2011). "Phenological niche separation from native species increases reproductive success of an invasive species: Alliaria petiolata (Brassicaceae)-garlic mustard." The Journal of the Torrey Botanical Society 138(4): 418-433. 
Facelli, J. M. and S. T. A. Pickett (1991). "Indirect effects of litter on woody seedlings subject to herb competition." Oikos 62: 129-138.

Fargen, C., S. M. Emery and M. M. Carreiro (2015). "Influence of Lonicera maackii invasion on leaf litter decomposition and macroinvertebrate communities in an urban stream." Natural Areas Journal 35(3): 392403.

Flory, S. and K. Clay (2006). "Invasive shrub distribution varies with distance to roads and stand age in eastern deciduous forests in Indiana, USA." Plant Ecology 184(1): 131-141.

Flory, S. L. and K. Clay (2009). "Effects of roads and forest successional age on experimental plant invasions." Biological Conservation 142(11): 2531-2537.

Flory, S. L. and K. Clay (2009). "Invasive plant removal method determines native plant community responses." Journal of Applied Ecology 46(2): 434-442.

Flory, S. L., J. A. Rudgers and K. Clay (2007). "Experimental light treatments affect invasion success and the impact of Microstegium vimineum on the resident community." Natural Areas Journal 27(2): 124-132.

Gorchov, D. L. and D. E. Trisel (2003). "Competitive effects of the invasive shrub, Lonicera maackii (Rupr.) Herder (Caprifoliaceae), on the growth and survival of native tree seedlings." Plant Ecology 166(1): 13-24.

Gould, A. M. A. and D. L. Gorchov (2000). "Effects of the Exotic Invasive Shrub Lonicera maackii on the Survival and Fecundity of Three Species of Native Annuals." The American Midland Naturalist 144(1): 3650 .

Hansen, A. J., R. Rasker, B. Maxwell, J. J. Rotella, J. D. Johnson, A. W. Parmenter, U. Langner, W. B. Cohen, R. L. Lawrence and M. P. Kraska (2002). "Ecological Causes and Consequences of Demographic Change in the New West As natural amenities attract people and commerce to the rural west, the resulting land-use changes threaten biodiversity, even in protected areas, and challenge efforts to sustain local communities and ecosystems." BioScience 52(2): 151-162.

Hartman, K. M. and B. C. McCarthy (2004). "Restoration of a Forest Understory After the Removal of an Invasive Shrub, Amur Honeysuckle (Lonicera maackii)." Restoration Ecology 12(2): 154-165.

Hartman, K. M. and B. C. McCarthy (2007). "A dendro-ecological study of forest overstorey productivity following the invasion of the non-indigenous shrub Lonicera maackii." Applied Vegetation Science 10(1): 3-14.

Hartman, K. M. and B. C. McCarthy (2008). "Changes in Forest Structure and Species Composition following Invasion by a Non-Indigenous Shrub, Amur Honeysuckle (Lonicera maackii)." Journal of the Torrey Botanical Society 135(2): 245-259.

Hausman, C. E., J. F. Jaeger and O. J. Rocha (2010). "Impacts of the emerald ash borer (EAB) eradication and tree mortality: potential for a secondary spread of invasive plant species." Biological Invasions 12(7): 2013-2023.

Hille Ris Lambers, J., J. S. Clark and M. Lavine (2005). "Implications of seed banking for recruitment of southern Appalachian woody species." Ecology 86(1): 85-95.

Hutchinson, T. F. and J. L. Vankat (1997). "Invasibility and effects of Amur honeysuckle in southwestern Ohio forests." Conservation Biology 11(5): 1117-1124.

Hutchinson, T. F. and J. L. Vankat (1998). "Landscape Structure and Spread of the Exotic Shrub Lonicera maackii (Amur honeysuckle) in Southwestern Ohio Forests." The American Midland Naturalist 139(2): 383-390. 
Hyatt, L. A. and B. B. Casper (2000). "Seed bank formation during early secondary succession in a temperate deciduous forest." Journal of Ecology 88(516): 516-527.

Knight, K. S., J. S. Kurylo, A. G. Endress, J. R. Stewart and P. B. Reich (2007). "Ecology and ecosystem impacts of common buckthorn (Rhamnus cathartica): a review." Biological Invasions 9(8): 925-937.

Kupfer, J. A. and J. R. Runkle (1996). "Early gap successional pathways in a Fagus-Acer forest preserve: pattern and determinants." Journal of Vegetation Science 7(2): 247-256.

Leckie, S., M. Vellend, G. Bell, M. J. Waterway and M. J. Lechowicz (2000). "The seed bank in an oldgrowth, temperate deciduous forest." Canadian Journal of Botany 78(2): 181-192.

Lemmon, P. E. (1956). "A spherical densiometer for estimating forest overstory density." Forest science 2(4): 314-320.

Levine, J. M., M. Vila, C. M. D'Antonio, J. S. Dukes, K. Grigulis and S. Lavorel (2003). "Mechanisms underlying the impacts of exotic plant invasions." Proc Biol Sci. 270: 775-781.

Lieurance, D. and K. Landsbergen (2016). "The influence of light habitat on the physiology, biomass allocation, and fecundity of the invasive shrub Amur honeysuckle (Lonicera maackii, Caprifoliaceae) 1." The Journal of the Torrey Botanical Society 143(4): 415-426.

Loeb, R. E., J. Germeraad, T. Treece, D. Wakefield and S. Ward (2010). "Effects of 1-year vs. annual treatment of Amur honeysuckle (Lonicera maackii) in forests." Invasive Plant Science and Management 3(3): 334-339.

Luken, J. O., L. M. Kuddes and T. C. Tholemeier (1997a). "Response of Understory Species to Gap Formation and Soil Disturbance m Lonicera maackii Thickets." Restoration Ecology 5(3): 229-235.

Luken, J. O., L. M. Kuddes, T. C. Tholemeier and D. M. Haller (1997b). "Comparative Responses of Lonicera maackii (Amur Honeysuckle) and Lindera benzoin (Spicebush) to Increased Light." American Midland Naturalist 138(2): 331-343.

Luken, J. O. and J. W. Thieret (1996). "Amur Honeysuckle, its fall from grace." BioScience 46(1): 18-24.

Lynch, K. R. (2016). "Effects of invasive shrub honeysuckle (Lonicera maackii) and forest composition on bird communities in woodland stands."

Masters, J. A. (2014). "Invasive plants as drivers and passengers of community change in a disturbed urban forest." Dissertation, University of Louisville.

Masters, J. A. and S. M. Emery (2015). "Leaf Litter Depth has only a Small Influence on Ranunculus ficaria (Ranunculaceae) Biomass and Reproduction." The American Midland Naturalist 173(1): 30-37.

Masters, J. A. and S. M. Emery (2016). "Do multiple mechanisms drive the dominance of an invasive plant (Ranunculus ficaria, Ranunculaceae) along an urban stream? 1." The Journal of the Torrey Botanical Society 143(4): 359-366.

Mattos, K. J. and J. L. Orrock (2010). "Behavioral consequences of plant invasion: an invasive plant alters rodent antipredator behavior." Behavioral Ecology 21(3): 556-561.

McEwan, R. W., M. A. Arthur and S. E. Alverson (2012). "Throughfall Chemistry and Soil Nutrient Effects of the Invasive Shrub Lonicera maackii in Deciduous Forests." The American Midland Naturalist 168(1): 43-55.

McEwan, R. W., M. K. Birchfield, A. Schoergendorfer and M. A. Arthur (2009). "Leaf Phenology and Freeze Tolerance of the Invasive Shrub Amur Honeysuckle and Potential Native Competitors." Journal of the Torrey Botanical Society 136(2): 212-220. 
McNeish, R. E. and R. W. McEwan (2016). "A review on the invasion ecology of Amur honeysuckle (Lonicera maackii, Caprifoliaceae) a case study of ecological impacts at multiple scales 1." The Journal of the Torrey Botanical Society 143(4): 367-385.

Meiners, S. J. (2007). "Apparent competition: an impact of exotic shrub invasion on tree regeneration." Biological Invasions 9(7): 849-855.

Miller, J. H. (2006). "Nonnative invasive plants of southern forests." USDA Forest Service/UNL Faculty Publications: 103.

Moore, E. R. (2015). "Plant community responses to invasive shrub and vine removal in an urban park woodland."

National Park Service, N. P. S. (2009). "Invasive Species.....What are they and why are they a problem?" Retrieved 10/12/2016, 2016, from http://www.nature.nps.gov/biology/invasivespecies/index.cfm.

Nielsen, A. B., M. van den Bosch, S. Maruthaveeran and C. K. van den Bosch (2014). "Species richness in urban parks and its drivers: A review of empirical evidence." Urban ecosystems 17(1): 305-327.

Natural Resources Conservation Service, USDA (2016). The PLANTS Database (http://plants. usda. gov, 31 October 2016). National Plant Data Team, Greensboro, NC 27401-4901.

Orrock, J. L., D. J. Levey, B. J. Danielson and E. I. Damschen (2006). "Seed predation, not seed dispersal, explains the landscape-level abundance of an early-successional plant." Journal of Ecology 94(4): 838-845.

Owen, H. R., A. McDonnell, A. Mounteer and B. Todd (2005). "Influence of stem cutting and glyphosate treatment of Lonicera maackii, an exotic and invasive species, on stem regrowth and native species richness." Transactions of the Illinois State Academy of Science 98(1\&2).

Pipal, R. P. (2014). "Earthworm, Microbial Biomass, and Leaf Litter Decay Responses After Invasive Honeysuckle Shrub Removal From Urban Woodlands." 174.

Poulette, M. M. and M. A. Arthur (2012). "The impact of the invasive shrub Lonicera maackii on the decomposition dynamics of a native plant community." Ecological Applications 22(2): 412-424.

Pyšek, P., V. Jarošík and T. Kučera (2002). "Patterns of invasion in temperate nature reserves." Biological Conservation 104(1): 13-24.

Redwood, M. E., G. R. Matlack and C. D. Huebner (2016). "Seed longevity and dormancy state in a disturbance-dependent forest herb, Ageratina altissima."

Reichard, S. H. and P. White (2001). "Horticulture as a Pathway of Invasive Plant Introductions in the United States Most invasive plants have been introduced for horticultural use by nurseries, botanical gardens, and individuals." BioScience 51(2): 103-113.

Rejmánek, M. (2013). "Extended leaf phenology: a secret of successful invaders?" Journal of vegetation science 24(6): 975-976.

Rooney, T. P. (2001). "Deer impacts on forest ecosystems: a North American perspective." Forestry 74(3): 201-208.

Ruhren, S. and S. N. Handel (2003). "Herbivory constrains survival, reproduction and mutualisms when restoring nine temperate forest herbs." Journal of the Torrey Botanical Society: 34-42.

Runkle, J. R., A. DiSalvo, Y. Graham-Gibson and M. Dorning (2007). "Vegetation release eight years after removal of Lonicera maackii in West-Central Ohio." 
Russell, F. L., D. B. Zippin and N. L. Fowler (2001). "Effects of white-tailed deer (Odocoileus virginianus) on plants, plant populations and communities: a review." The American Midland Naturalist 146(1): 1-26.

Sakai, A. N., F. W. Allendorf, J. S. Holt, D. M. Lodge, J. Molofsky, K. A. With, S. Baughman, R. J. Cabin, J. E. Cohen, N. C. Ellstrand, D. E. McCauley, P. O'Neil, I. M. Parker, J. N. Thompson and S. G. Weller (2001). "The population biology of invasive species." Annual Review of Ecological Systematics 32: 305332.

Scott, J. M., F. W. Davis, R. G. McGhie, R. G. Wright, C. Groves and J. Estes (2001). "Nature reserves: Do they capture the full range of America's biological diversity?" Ecological Applications 11(4): 999-1007.

Shea, M., D. White, M. Evans, and D. M. Ladd. (No date.). Kentucky coefficients of conservatism. Unpublished data.

Smith, L. (2013). "Extended leaf phenology in deciduous forest invaders: mechanisms of impact on native communities." Journal of vegetation science 24(6): 979-987.

Smith, L. M. and H. L. Reynolds (2012). "Positive plant-soil feedback may drive dominance of a woodland invader, Euonymus fortunei." Plant Ecology 213(5): 853-860.

Swab, R. M., L. Zhang and W. J. Mitsch (2008). "Effect of Hydrologic Restoration and Lonicera maackii Removal on Herbaceous Understory Vegetation in a Bottomland Hardwood Forest." Restoration Ecology 16(3): 453-463.

Swink, F. and G. Wilhelm (1994). Plants of the Chicago region, Indiana Academy of Science Indianapolis.

Tilman, D. (1997). "Community invasibility, recruitment limitation, and grassland biodiversity." Ecology 78(1): 81-92.

Trammell, T. E., H. Ralston, S. Scroggins and M. Carreiro (2012). "Foliar production and decomposition rates in urban forests invaded by the exotic invasive shrub, Lonicera maackii." Biological Invasions 14(3): 529-545.

Trammell, T. L. and M. M. Carreiro (2011). "Vegetation composition and structure of woody plant communities along urban interstate corridors in Louisville, KY, USA." Urban Ecosystems 14(4): 501-524.

Trisel, D. (1997). "The invasive shrub, Lonicera maackii (Rupr.) Herder (Caprifoliaceae) factors leading to its success and its effect on native species." PhD Dissertation: 200.

Vidra, R. L., T. H. Shear and T. R. Wentworth (2006). "Testing the paradigms of exotic species invasion in urban riparian forests." Natural Areas Journal 26(4): 339-350.

Vitousek, P. M., C. M. D'antonio, L. L. Loope, M. Rejmanek and R. Westbrooks (1997). "Introduced species: a significant component of human-caused global change." New Zealand Journal of Ecology: 1-16.

Vitousek, P. M., H. A. Mooney, J. Lubchenco and J. M. Melillo (1997). "Human domination of Earth's ecosystems." Science 277(5325): 494-499.

Wainwright, C. E. and E. E. Cleland (2013). "Exotic species display greater germination plasticity and higher germination rates than native species across multiple cues." Biological Invasions 15(10): 2253-2264.

Webster, C. R., M. A. Jenkins and S. Jose (2006). "Woody invaders and the challenges they pose to forest ecosystems in the eastern United States." Journal of Forestry 104(7): 366-374.

White, R. J., M. M. Carreiro and W. C. Zipperer (2014). "Woody plant communities along urban, suburban, and rural streams in Louisville, Kentucky, USA." Urban Ecosystems: 1-34. 
Yelenik, S. G. and J. M. Levine (2011). "The role of plant—soil feedbacks in driving native-species recovery." Ecology 92(1): 66-74. 


\begin{tabular}{|c|c|c|c|c|c|}
\hline & Season & Control & Removal & $\mathrm{p}$-value & Reference \\
\hline \multirow[t]{2}{*}{ Species Richness (R) } & Spring & $13.8(1.35)$ & $21.4(2.58)$ & 0.008 & $19.7(2.40)$ \\
\hline & Summer & $9.5(1.59)$ & $17.9(2.05)$ & 0.017 & $10.7(0.88)$ \\
\hline \multirow[t]{2}{*}{ Exotic (R) } & Spring & $3.75(0.412)$ & $5.5(0.845)$ & 0.076 & $2.33(0.33)$ \\
\hline & Summer & $1.38(0.375)$ & $2.5(0.327)$ & 0.017 & $1.0(0.58)$ \\
\hline \multirow[t]{2}{*}{ Native (R) } & Spring & $10(1.35)$ & $15.9(2.05)$ & 0.008 & $17.3(2.19)$ \\
\hline & Summer & $8.13(1.46)$ & $15.4(2.00)$ & 0.020 & $9.67(0.89)$ \\
\hline \multirow[t]{2}{*}{$\begin{array}{c}\text { Shannon's Diversity } \\
\left(\mathrm{H}^{\prime}\right)\end{array}$} & Spring & $0.954(0.195)$ & $1.64(0.285)$ & $0.050 *$ & $1.47(0.26)$ \\
\hline & Summer & $1.39(0.215)$ & $1.35(0.157)$ & $0.902 *$ & $1.09(0.09)$ \\
\hline \multirow[t]{2}{*}{$\begin{array}{c}\text { Shannon's } \\
\text { Equitability (J) }\end{array}$} & Spring & $0.348(0.067)$ & $0.547(0.097)$ & $0.104^{*}$ & $0.49(0.07)$ \\
\hline & Summer & $0.594(0.089)$ & $0.482(0.059)$ & $0.483^{*}$ & $0.46(0.02)$ \\
\hline Simpson's D & $\begin{array}{l}\text { Spring } \\
\text { Summer }\end{array}$ & $2.02(0.34)$ & $\begin{array}{l}4.56(1.11) \\
2.94(0.54)\end{array}$ & $\begin{array}{l}0.053^{*} \\
0.524^{*}\end{array}$ & $2.69(0.66)$ \\
\hline \multirow[t]{2}{*}{ Herb Cover (\%) } & Spring & $10.5(4.17)$ & $\begin{array}{l}2.94(0.54) \\
17.9(7.39)\end{array}$ & 0.648 & $\begin{array}{l}2.04(0.25) \\
17.1(3.72)\end{array}$ \\
\hline & Summer & $2.32(0.87)$ & $16.7(5.34)$ & 0.024 & $5.56(1.82)$ \\
\hline \multirow{2}{*}{$\begin{array}{c}\text { Exotic } \\
\text { Cover }(\%)\end{array}$} & Spring & $1.36(0.66)$ & $10.7(5.86)$ & 0.050 & $0.30(0.07)$ \\
\hline & Summer & $0.26(0.11)$ & $0.25(0.07)$ & 0.327 & $0.71(0.60)$ \\
\hline \multirow{2}{*}{$\begin{array}{c}\text { Native } \\
\text { Cover }(\%)\end{array}$} & Spring & $9.17(4.39)$ & $7.75(3.46)$ & 0.670 & $16.9(3.67)$ \\
\hline & Summer & $2.06(0.78)$ & $16.5(5.3)$ & 0.023 & $8.25(1.75)$ \\
\hline
\end{tabular}




\begin{tabular}{|c|c|c|c|c|c|}
\hline & & 2008 & 2013 & 2-Factor Test & p-value \\
\hline \multirow{3}{*}{$\begin{array}{l}\text { Spring Herb Spp. } \\
\text { Richness, R }\end{array}$} & Control: & 6.37 & 13.75 & Year & 0.008 \\
\hline & & (2.04) & $(1.35)$ & Treatment & 0.013 \\
\hline & Removal: & $\begin{array}{l}7.75 \\
(2.3)\end{array}$ & $\begin{array}{l}21.38 \\
(2.58)\end{array}$ & Year*Treatment & 0.102 \\
\hline \multirow{3}{*}{$\begin{array}{l}\text { Summer Herb Spp. } \\
\text { Richness, R }\end{array}$} & Control: & 5.5 & 9.5 & Year & 0.010 \\
\hline & & $(1.78)$ & (1.59) & Treatment & 0.016 \\
\hline & Removal: & $\begin{array}{l}5.125 \\
(1.62)\end{array}$ & $\begin{array}{l}17.9 \\
(2.05)\end{array}$ & Year*Treatment & 0.011 \\
\hline \multirow{3}{*}{$\begin{array}{l}\text { Summer Vine Spp. } \\
\text { Richness, R }\end{array}$} & Control: & 2.38 & 5.25 & Year & 0.008 \\
\hline & & $(0.26)$ & $(0.45)$ & Treatment & 0.782 \\
\hline & Removal: & $\begin{array}{c}2.13 \\
(0.48)\end{array}$ & $\begin{array}{c}6.63 \\
(0.46)\end{array}$ & Year*Treatment & 0.082 \\
\hline \multirow[t]{2}{*}{ Spring Herb H' } & Control & 0.77 & 0.95 & $\begin{array}{c}\text { Year } \\
\text { Treatment }\end{array}$ & 0.435 \\
\hline & Removal & $\begin{array}{l}1.13 \\
(0.24)\end{array}$ & $\begin{array}{l}1.64 \\
(0.29)\end{array}$ & Year*Treatment & 0.564 \\
\hline \multirow[t]{3}{*}{ Summer Herb H' } & Control: & 0.66 & 1.39 & Year & 0.090 \\
\hline & & $(0.19)$ & $(0.22)$ & Treatment & 0.974 \\
\hline & Removal: & $\begin{array}{c}0.60 \\
(0.21)\end{array}$ & $\begin{array}{l}1.35 \\
(0.16)\end{array}$ & Year*Treatment & 0.530 \\
\hline \multirow[t]{3}{*}{ Spring Herb J } & Control & 0.49 & 0.35 & Year & 0.208 \\
\hline & & $(0.07)$ & $(0.07)$ & Treatment & 0.023 \\
\hline & Removal & $\begin{array}{c}0.64 \\
(0.05)\end{array}$ & $\begin{array}{c}0.55 \\
(0.10)\end{array}$ & Year*Treatment & 0.782 \\
\hline \multirow[t]{3}{*}{ Summer Herb J } & Control: & 0.50 & 0.59 & Year & 0.989 \\
\hline & & $(0.11)$ & $(0.09)$ & Treatment & 0.917 \\
\hline & Removal: & $\begin{array}{c}0.58 \\
(0.12)\end{array}$ & $\begin{array}{c}0.48 \\
(0.06)\end{array}$ & Year*Treatment & 0.486 \\
\hline \multirow{3}{*}{$\begin{array}{c}\text { Spring Herb Cover } \\
(\%)\end{array}$} & Control & 13.49 & 10.53 & Year & 0.435 \\
\hline & & $(5.04)$ & (4.17) & Treatment & 0.630 \\
\hline & Removal & $\begin{array}{c}7.17 \\
(3.25)\end{array}$ & $\begin{array}{l}17.92 \\
(7.39)\end{array}$ & Year*Treatment & 0.797 \\
\hline \multirow{3}{*}{$\begin{array}{c}\text { Summer Herb Cover } \\
(\%)\end{array}$} & Control & 4.93 & 2.32 & Year & 0.132 \\
\hline & & $(3.07)$ & $(0.81)$ & Treatment & 0.208 \\
\hline & Removal & $\begin{array}{c}1.28 \\
(0.68)\end{array}$ & $\begin{array}{l}16.74 \\
(5.34)\end{array}$ & Year*Treatment & 0.010 \\
\hline \multirow[t]{3}{*}{ Vine Cover (\%) } & Control: & 1.21 & 2.49 & Year & 0.008 \\
\hline & & $(0.51)$ & $(0.99)$ & Treatment & 0.102 \\
\hline & Removal: & $\begin{array}{c}1.09 \\
(0.59)\end{array}$ & $\begin{array}{c}11.8 \\
(5.36)\end{array}$ & Year*Treatment & 0.057 \\
\hline
\end{tabular}


Table 3. Light related factors and key plant responses in removal plots. Plots ordered by distance of plot center to nearest open area as defined in Methods. Canopy cover is mean \% closed canopy on spherical densiometer (2014: mean of measurements facing each cardinal direction at $1.25 \mathrm{~m}$; 2013: north facing at $<10 \mathrm{~cm}$ ) measured in summer. LAI is Leaf Area Index in $\mathrm{m}^{2}$ of non-Lonicera maackii leaf area per $\mathrm{m}^{2}$ of ground area (n.m. = not measured at that site; see Methods for explanation). Canopy category is based on the integration of measures that influence light entry into plots (Distance to open area, \% canopy cover and LAI). Minimum known presence (MKP) of Lonicera maackii at time of cutting in 2008 is listed in years.

\begin{tabular}{|c|c|c|c|c|c|c|c|c|}
\hline & 4 & 9 & 8 & 2 & 3 & 6 & 5 & 1 \\
\hline Aspect & $\mathrm{S}$ & SW & $\mathrm{W}$ & $\mathrm{SE}$ & $\mathrm{W}$ & $\mathrm{W}$ & $\mathrm{E}$ & NW \\
\hline$\left(0^{\circ}=\right.$ North $)$ & $158^{\circ}$ & $228^{\circ}$ & $253^{\circ}$ & $148^{\circ}$ & $271^{\circ}$ & $277^{\circ}$ & $101^{\circ}$ & $334^{\circ}$ \\
\hline $\begin{array}{l}\text { Distance to nearest } \\
\text { Open Area (m) }\end{array}$ & 11.3 & 13.2 & 16.5 & 29.3 & 30.2 & 31 & 41.4 & 48.6 \\
\hline $\begin{array}{c}\text { Canopy Cover } \\
(2014, \%)\end{array}$ & 88.8 & 97.7 & 92.7 & 92.2 & 97.4 & 93.8 & 96.4 & 96.4 \\
\hline $\begin{array}{c}\text { Canopy Cover (2013, } \\
\%)\end{array}$ & 89.1 & 88.5 & 93.9 & 93.8 & 90.2 & 95.1 & 96.4 & 93.3 \\
\hline $\begin{array}{c}\text { LAI(2010) } \\
\text { Canopy Category: }\end{array}$ & $\begin{array}{l}1.91 \\
\text { open }\end{array}$ & $\begin{array}{l}\text { n.m. } \\
\text { open }\end{array}$ & $\begin{array}{l}\text { n.m. } \\
\text { open }\end{array}$ & $\begin{array}{c}2.8 \\
\text { open }\end{array}$ & $\begin{array}{c}3.32 \\
\text { shade }\end{array}$ & $\begin{array}{l}4.03 \\
\text { shade }\end{array}$ & $\begin{array}{c}6.27 \\
\text { shade }\end{array}$ & $\begin{array}{l}\text { n.m. } \\
\text { shade }\end{array}$ \\
\hline $\begin{array}{l}\text { Minimum Known } \\
\text { Presence (MKP) }\end{array}$ & 25 & 31 & 24 & 29 & 17 & 19 & 22 & 19 \\
\hline $\begin{array}{c}\text { Spring herb cover } \\
(2013, \%)\end{array}$ & 36.4 & 22.0 & 4.80 & 59.0 & 0.28 & 0.80 & 2.54 & 17.5 \\
\hline $\begin{array}{c}\text { Summer herb cover } \\
(2013, \%)\end{array}$ & 37.9 & 22.2 & 35.4 & 23.8 & 1.27 & 1.33 & 3.30 & 8.72 \\
\hline $\begin{array}{l}\text { Woody seedlings } \\
\left(2013, \# \text { ha }^{-1}\right)\end{array}$ & 23900 & 18300 & 41100 & 99300 & 17800 & 188400 & 34400 & 57100 \\
\hline $\begin{array}{c}\text { L. maackii stems } \\
0.3 \mathrm{~m}-0.99 \mathrm{~m} \\
\left(2013, \# \mathrm{ha}^{-1}\right)\end{array}$ & 14,400 & 8,000 & 90,500 & 46,800 & 21,900 & 16,600 & 12,400 & 10,300 \\
\hline $\begin{array}{l}\text { Shrub stems } \\
0.3 \mathrm{~m}-0.99 \mathrm{~m} \\
\left(2013, \# \mathrm{ha}^{-1}\right)\end{array}$ & 14,400 & 19,100 & 90,700 & 47,500 & 21,900 & 34,500 & 14,400 & 12,400 \\
\hline
\end{tabular}


Table 4. Woody plant seedling density (2013). Values are mean number of seedlings ha ${ }^{-1}$ ( \pm 1 S.E.) in the given treatment. P-values are from 2-tailed paired t-tests between Control and Removal and are corrected for False Discovery Rate (FDR) using Proc Multtest (SAS, v9.3). P-value for tree seedlings (marked with asterisk) is for a 1-tailed paired t-test (Removal > Control).

\begin{tabular}{ccccc}
\hline & Control & Removal & p-value & Reference \\
\hline Vines & 5,525 & 7,438 & 0.298 & 27,833 \\
& $(1,151)$ & $(710)$ & & $(16,852.9)$ \\
Trees & 24,963 & 47,788 & $0.255^{*}$ & 1,600 \\
& $(8,657)$ & $(20,689)$ & & $(378.6)$ \\
Shrubs & 16,563 & 4,813 & 0.428 & 733.3 \\
& $(7,232)$ & $(1,359)$ & & $(384.4)$ \\
Total & 47,050 & 60,037 & 0.714 & $30,233.3$ \\
& $(14,202)$ & $(20,648)$ & & $(17,513.6)$ \\
\hline
\end{tabular}


Table 5. Vine and shrub species richness (2013). Values are mean number of species ( \pm 1S.E.) in plots by treatment. P-values are corrected for False Discovery Rate (FDR) using a 2-tailed paired t-test. Pvalues marked with an asterisk $(*)$ are FDR-corrected Wilcoxon Ranked Sign test results used because data were non-parametric.

\begin{tabular}{ccccc}
\hline & Control & Removal & p-value & Reference \\
\hline All Vines & 5.25 & 6.63 & 0.050 & 5.0 \\
& $(0.453)$ & $(0.46)$ & & $(1.15)$ \\
Exotic Vines & 2.38 & 3.13 & $0.113^{*}$ & 3.0 \\
& $(0.183)$ & $(0.295)$ & & $(0.58)$ \\
Native Vines & 2.88 & 3.50 & $0.521^{*}$ & 2.0 \\
& $(0.40)$ & $(0.463)$ & & $(1.0)$ \\
All Shrubs & 1.88 & 2.13 & $0.793^{*}$ & 2.0 \\
& $(0.295)$ & $(0.300)$ & & $(0.67)$ \\
Exotic Shrubs & 1.63 & 1.75 & $1.00^{*}$ & 0.67 \\
& $(0.183)$ & $(0.163)$ & & $(0.33)$ \\
Native Shrubs & 0.25 & 0.375 & $1.00^{*}$ & 1.0 \\
& $(0.164)$ & $(0.183)$ & & $(0.58)$ \\
\hline
\end{tabular}


Table 6. Spring and Summer (2013) Vine Cover. Data are means ( \pm 1S.E.) $(\mathrm{N}=8$ for control and removal, $\mathrm{N}=3$ for reference) of percent cover. $\mathrm{P}$-values are from 1-tailed paired t-tests (Control < Removal) and are corrected for False Discovery Rate (FDR) using Proc Multtest (SAS, v9.3). Asterisk, *, denotes p-value for a Wilcoxon Ranked Sign test used due to non-normal data.

\begin{tabular}{cccccc} 
& & Control & Removal & p-value & Reference \\
\hline \multirow{3}{*}{ Spring } & All & $11.9(7.38)$ & $10.8(5.15)$ & 0.601 & $22.9(16.9)$ \\
& Exotic & $3.03(1.24)$ & $10.1(4.95)$ & 0.147 & $22.9(16.9)$ \\
& Native & $8.96(7.69)$ & $0.71(0.56)$ & 0.255 & $0.02(0.01)$ \\
& & & & & \\
\multirow{3}{*}{ Summer } & & Control & Removal & p-value & Reference \\
& All & $2.49(0.99)$ & $11.8(5.36)$ & 0.053 & $28.7(23.9)$ \\
& Exotic & $2.23(0.99)$ & $9.89(5.49)$ & 0.170 & $28.5(23.9)$ \\
& Native & $0.26(0.06)$ & $1.95(1.42)$ & $0.076^{*}$ & $0.21(0.11)$ \\
\hline
\end{tabular}




\begin{tabular}{|c|c|c|c|c|c|}
\hline & & 2008 & 2013 & 2-Factor Test & $\mathrm{p}$-value \\
\hline \multirow{3}{*}{$\begin{array}{l}\text { Tree Seedling } \\
\text { Richness }\end{array}$} & Control: & 5.38 & 8.75 & Year & 0.010 \\
\hline & & $(1.08)$ & $(0.726)$ & Treatment & 0.548 \\
\hline & Removal: & $\begin{array}{l}4.00 \\
(0.85)\end{array}$ & $\begin{array}{c}9.25 \\
(0.726)\end{array}$ & Year*Treatment & 0.196 \\
\hline \multirow{3}{*}{$\begin{array}{l}\text { Tree Seedling } \\
\text { Density }\left(\# \mathrm{ha}^{-1}\right)\end{array}$} & Control & 5,900 & 24,963 & Year & 0.008 \\
\hline & & $(1,612)$ & $(8,657)$ & Treatment & 0.917 \\
\hline & Removal & $\begin{array}{c}4,363 \\
(1,381)\end{array}$ & $\begin{array}{c}47,788 \\
(20,688)\end{array}$ & Year*Treatment & 0.323 \\
\hline \multirow{3}{*}{$\begin{array}{l}\text { Vine Seedling } \\
\text { Density }\left(\# \text { ha }^{-1}\right)\end{array}$} & Control & 9,800 & 5,525 & Year & 0.797 \\
\hline & & $(4,211)$ & $(1,151)$ & Treatment & 0.805 \\
\hline & Removal & $\begin{array}{c}6,563 \\
(3,438)\end{array}$ & $\begin{array}{l}7,438 \\
(710)\end{array}$ & Year*Treatment & 0.210 \\
\hline \multirow{3}{*}{$\begin{array}{l}\text { Shrub Seedling } \\
\text { Density }\left(\# \mathrm{ha}^{-1}\right)\end{array}$} & Control: & 3,538 & 16,563 & Year & 0.0997 \\
\hline & & $(450)$ & $(7,233)$ & Treatment & 0.291 \\
\hline & Removal: & $\begin{array}{c}3,863 \\
(1,319)\end{array}$ & $\begin{array}{c}4,813 \\
(1,359)\end{array}$ & Year*Treatment & 0.530 \\
\hline \multirow{3}{*}{$\begin{array}{c}\text { Lonicera spp. } \\
\text { Seedling Density (\# } \\
\text { ha }^{-1} \text { ) }\end{array}$} & Control & 2,425 & 15,837 & Year & 0.014 \\
\hline & & (586) & $(7,309)$ & Treatment & 0.328 \\
\hline & Removal & $\begin{array}{l}1,650 \\
(330)\end{array}$ & $\begin{array}{c}4,337 \\
(1,413)\end{array}$ & Year*Treatment & 0.805 \\
\hline \multirow[t]{3}{*}{ Sapling Richness } & Control: & 1.88 & 2.63 & Year & 0.435 \\
\hline & & $(0.64)$ & $(0.53)$ & Treatment & 0.435 \\
\hline & Removal: & $\begin{array}{l}2.75 \\
(0.92)\end{array}$ & $\begin{array}{c}4.00 \\
(0.00)\end{array}$ & Year*Treatment & 0.188 \\
\hline \multirow{3}{*}{$\begin{array}{l}\text { Sapling Density (\# } \\
\mathrm{ha}^{-1} \text { ) }\end{array}$} & Control & 4.63 & 16.6 & Year & 0.010 \\
\hline & & $(1.79)$ & $(6.06)$ & Treatment & 0.023 \\
\hline & Removal & $\begin{array}{c}9.50 \\
(3.59)\end{array}$ & $\begin{array}{c}57.0 \\
(20.1)\end{array}$ & Year*Treatment & 0.046 \\
\hline
\end{tabular}


Table 8. Tree seedling and sapling richness and density (2013). Values are means ( \pm 1 S.E.) $(\mathrm{N}=8$ for control and removal; $\mathrm{N}=3$ for reference). $\mathrm{P}$-values are from 1-tailed paired t-test (Removal $>$ Control), corrected for False Discovery Rate (FDR) using Proc Multtest (SAS v9.3).

\begin{tabular}{ccccc} 
& Control & Removal & p-value & Reference \\
Seedlings & & & & \\
\hline Species Richness (R) & $8.75(0.73)$ & $9.25(0.73)$ & 0.257 & $9.0(0.58)$ \\
Exotic R & $0.875(0.23)$ & $0.875(0.125)$ & 0.583 & $0.33(0.33)$ \\
Native R & $7.88(0.71)$ & $8.38(0.68)$ & 0.357 & $8.67(0.33)$ \\
Density (\# ha $\left.{ }^{-1}\right)$ & $24,963(8,657)$ & $47,788(20,689)$ & 0.255 & $27,833(16,853)$ \\
& & & \\
Saplings & & & & \\
\hline Species Richness (R) & $3.38(0.84)$ & $5.25(0.41)$ & 0.050 & $6.33(2.19)$ \\
Exotic R & $0.625(0.183)$ & $0.5(0.267)$ & 0.456 & $0.33(0.33)$ \\
Native R & $2.0(0.42)$ & $3.5(0.27)$ & 0.024 & $6.0(2)$ \\
Density (\# ha $\left.{ }^{-1}\right)$ & $16,625(606)$ & $57,000(2,009)$ & 0.024 & $13,600(9,760)$ \\
\hline
\end{tabular}


Table 9. Shrub stem density (2013). Values are mean number of live stems ( \pm 1S.E.) (N $=8$ for control and removal; $\mathrm{N}=3$ for reference) counted from shrubs of the given height class. P-values are from 2tailed paired t-tests, except those marked with asterisks, *, which are from 1-tailed paired T-test of Control > Removal. All p-values are corrected for False Discovery Rate (FDR) using Proc Multtest (SAS v9.3).

\begin{tabular}{ccccc}
\hline & & & & \\
All species & Control & Removal & p-value & Reference \\
\hline $0.3 \mathrm{~m}-1.0 \mathrm{~m}$ & $75.4(18.7)$ & $318.6(94.2)$ & 0.050 & $32.0(30.5)$ \\
$1.0 \mathrm{~m}-1.99 \mathrm{~m}$ & $64.8(13.7)$ & $119.4(30.9)$ & 0.056 & $10.0(8.02)$ \\
$\geq 2.0 \mathrm{~m}$ & $88.0(11.4)$ & $13.0(4.8)$ & 0.003 & $6.0(5.67)$ \\
All stems $\geq 0.3 \mathrm{~m}$ & $240(31.5)$ & $439(110)$ & 0.075 & $47.7(36.0)$ \\
& & & & \\
Lonicera sp. & Control & Removal & p-value & Reference \\
\hline $0.3 \mathrm{~m}-1.0 \mathrm{~m}$ & $70.1(18.1)$ & $276.1(99.7)$ & $0.061^{*}$ & $30.7(29.2)$ \\
$1.0 \mathrm{~m}-1.99 \mathrm{~m}$ & $41.6(8.4)$ & $64.8(19.1)$ & $0.160^{*}$ & $9.0(8.5)$ \\
$\geq 2.0 \mathrm{~m}$ & $84.1(11.3)$ & $7.5(2.1)$ & $0.003^{*}$ & $6.0(5.67)$ \\
All stems $\geq 0.3 \mathrm{~m}$ & $196(26.9)$ & $348(118)$ & 0.055 & $45.3(35.4)$ \\
\hline
\end{tabular}


Table 10. Soil type and slopes. $\mathrm{H}=$ Experimental paired plots, Ref. $=$ Reference plots. $\mathrm{C}=$ Control plot (Lonicera maackii uncut), $\mathrm{R}=$ Removal plot (L. maackii. cut and removed). North aspect is $0^{\circ}$. LAI is Leaf Area Index in $\mathrm{m}^{2}$ of non-Lonicera spp. litter-fall leaf area per $\mathrm{m}^{2}$ of ground. LAI was not measured in plots labelled 'n.m.' See Methods for explanation.

\begin{tabular}{|c|c|c|c|c|c|}
\hline $\begin{array}{l}\text { Treatment } \\
\text { Level }\end{array}$ & Aspect $\left({ }^{\circ}\right)$ & $\begin{array}{l}\text { Aspect } \\
\text { Facing }\end{array}$ & Mean \% slope & Soil Type & LAI in 2010 \\
\hline $\mathrm{H} 1-\mathrm{C}$ & 332 & NW & 12 & Crider & n.m. \\
\hline $\mathrm{H} 1-\mathrm{R}$ & 334 & NW & 12 & Crider & n.m. \\
\hline $\mathrm{H} 2-\mathrm{C}$ & 158 & S & up $28 \%$, lower $35 \%$ & Caneyville & 3.02 \\
\hline $\mathrm{H} 2-\mathrm{R}$ & 148 & SE & up $28 \%$, lower $35 \%$ & Caneyville & 2.8 \\
\hline $\mathrm{H} 3-\mathrm{C}$ & 271 & $\mathrm{~W}$ & 18 & Crider & 3.66 \\
\hline H3-R & 271 & $\mathrm{~W}$ & 18 & Crider & 3.32 \\
\hline $\mathrm{H} 4-\mathrm{C}$ & 149 & SE & 40 & Caneyville & 2.24 \\
\hline $\mathrm{H} 4-\mathrm{R}$ & 158 & $S$ & 40 & Caneyville & 1.91 \\
\hline $\mathrm{H} 5-\mathrm{C}$ & 105 & $\mathrm{E}$ & 30 up, $40 \%$ lower & Upper Crider & 5.68 \\
\hline H5-R & 101 & $\mathrm{E}$ & 30 up, $40 \%$ lower & Upper Crider & 6.27 \\
\hline $\mathrm{H} 6-\mathrm{C}$ & 252 & $\mathrm{~W}$ & 12 & Crider & 4.48 \\
\hline H6-R & 277 & $\mathrm{~W}$ & 12 & Crider & 4.03 \\
\hline $\mathrm{H} 8-\mathrm{C}$ & 259 & $\mathrm{~W}$ & 23 & Caneyville & n.m. \\
\hline H8-R & 253 & $\mathrm{~W}$ & 23 & Caneyville & n.m. \\
\hline $\mathrm{H} 9-\mathrm{C}$ & 237 & SW & 5 & Elk & n.m. \\
\hline H9-R & 228 & SW & 5 & Elk & n.m. \\
\hline Ref-1 & 332 & NW & 14 & Alford & n.m. \\
\hline Ref-2 & 347 & $\mathrm{~N}$ & 20 & Alford & n.m. \\
\hline Ref-4 & 100 & E & 30 up, $40 \%$ lower & Upper Crider & n.m. \\
\hline
\end{tabular}


Table 11. Variables that are sunlight-proxies and their correlation with summer (2013) herb cover in removal plots. Table of Pearson's $r$ product-moment correlation coefficients ( $p$-values in parentheses beneath each $\mathrm{r}$-value). Aspect values were the absolute value of degrees from north (north defined as $0^{\circ}$; $0^{\circ} \leq \mathrm{y} \leq 180 \mathrm{o}$ ) rather than compass degrees. * Leaf Area Index (LAI) was collected for only five sites, correlation only performed on those five sites $(\mathrm{N}=5)$. Other correlations for removal plots of the 8 paired experimental sites $(\mathrm{N}=8)$.

\begin{tabular}{ccc}
\hline & Summer Herb Cover $(\%)$ & p-value \\
\hline Summer Herb Cover $(\%)$ & 1 & - \\
Meters to forest edge & -0.754 & 0.031 \\
Canopy cover $(\%)$ & -0.693 & 0.057 \\
LAI $^{*}$ & -0.717 & 0.017 \\
Aspect $\left({ }^{\circ}\right.$ from North) & 0.649 & 0.082 \\
\hline
\end{tabular}


Table 12. Soil Series and classification of soils found at experimental and reference sites.

\begin{tabular}{cl}
\hline Soil Series & \multicolumn{1}{c}{ Classification } \\
\hline Crider & Fine-silty, mixed, active, mesic Typic Paleudalfs \\
Caneyville & Fine, mixed, active, mesic Typic Hapludalfs \\
Upper Crider & Fine-silty, mixed, active, mesic Typic Paleudalfs \\
Elk & Fine-silty, mixed, active, mesic Ultic Hapludalfs \\
Alford & Fine-silty, mixed, superactive, mesic Ultic Hapludalfs \\
\hline
\end{tabular}


Table 13. Canopy cover measurements. Canopy cover in percent was measured by densiometer was taken at $1.25 \mathrm{~m}$ height in 2014 and $<10 \mathrm{~cm}$ height in 2013. FWD $=$ Fine Woody Debris. FWD and litter mass are in grams oven dry mass $\left(\mathrm{gODM} \mathrm{m}^{-2}\right)$. Values are means $( \pm 1 \mathrm{~S}$.E. $)(\mathrm{N}=8$ for control and removal; $\mathrm{N}=3$ for reference). P-values are corrected for False Discovery Rate (FDR) using Proc Multtest (SAS, v9.3).

\begin{tabular}{ccccc}
\hline & Control & Removal & p-value & Reference \\
\hline $\begin{array}{c}\text { Canopy cover } \\
(2014, \%)\end{array}$ & $97.2(0.425)$ & $94.4(0.016)$ & 0.008 & $95.5(2.18)$ \\
$\begin{array}{c}\text { Canopy cover } \\
(2013, \%)\end{array}$ & $95.2(0.98)$ & $92.6(1.02)$ & 0.017 & $96.4(1.28)$ \\
$\begin{array}{c}\text { Litter Mass } \\
\left.(\mathrm{gODM} \mathrm{m})^{-2}\right)\end{array}$ & $96.4(33.5)$ & $69.4(33.5)$ & 0.237 & $269.6(58.7)$ \\
$\begin{array}{l}\text { FWD } \\
\left(\mathrm{gODM} \mathrm{m}^{-2}\right)\end{array}$ & $91.6(31.8)$ & $279.9(29.2)$ & 0.050 & $231.8(32.4)$ \\
\hline
\end{tabular}




\begin{tabular}{|c|c|c|c|}
\hline & "shade" & “open” & $\mathrm{p}$-value \\
\hline Herb Species Richness (R) & $15.75(2.29)$ & $20.0(3.37)$ & 0.648 \\
\hline Herb Community Diversity (H') & $1.70(0.15)$ & $1.00(0.10)$ & 0.044 \\
\hline Herb Community Evenness $(\mathrm{J})$ & $0.624(0.04)$ & $0.34(0.03)$ & 0.011 \\
\hline Herb Cover $(\%)$ & $3.66(1.75)$ & $29.8(3.98)$ & 0.011 \\
\hline Exotic Herb Cover $(\%)$ & $0.11(0.044)$ & $0.42(0.20)$ & 0.735 \\
\hline Vine Species Richness (R) & $7.25(0.75)$ & $6.0(0.41)$ & 0.648 \\
\hline Vine Cover $(\%)$ & $7.58(3.89)$ & $16.1(10.3)$ & 0.735 \\
\hline Tree Seedling Species Richness (R) & $9.5(1.04)$ & $9.0(1.15)$ & 0.875 \\
\hline Vine Seedling Density $\left(\# \mathrm{ha}^{-1}\right)$ & $7,550(729)$ & $7,330(1,350)$ & 0.951 \\
\hline Tree Seedling Density $\left(\# \mathrm{ha}^{-1}\right)$ & $63,050(39,396)$ & $32,525(17,028)$ & 0.875 \\
\hline Sapling Species Richness (R) & $5.75(0.63)$ & $4.75(0.48)$ & 0.648 \\
\hline Sapling Density $\left(\# h^{-1}\right)$ & $7,625(3,968)$ & $3,775(786)$ & 0.875 \\
\hline $\begin{array}{l}\text { Shrub Stem Density }>0.3 \mathrm{~m} \\
\left(\# \mathrm{ha}^{-1}\right)\end{array}$ & $32,675(11,657)$ & $57,200(18,692)$ & 0.648 \\
\hline
\end{tabular}




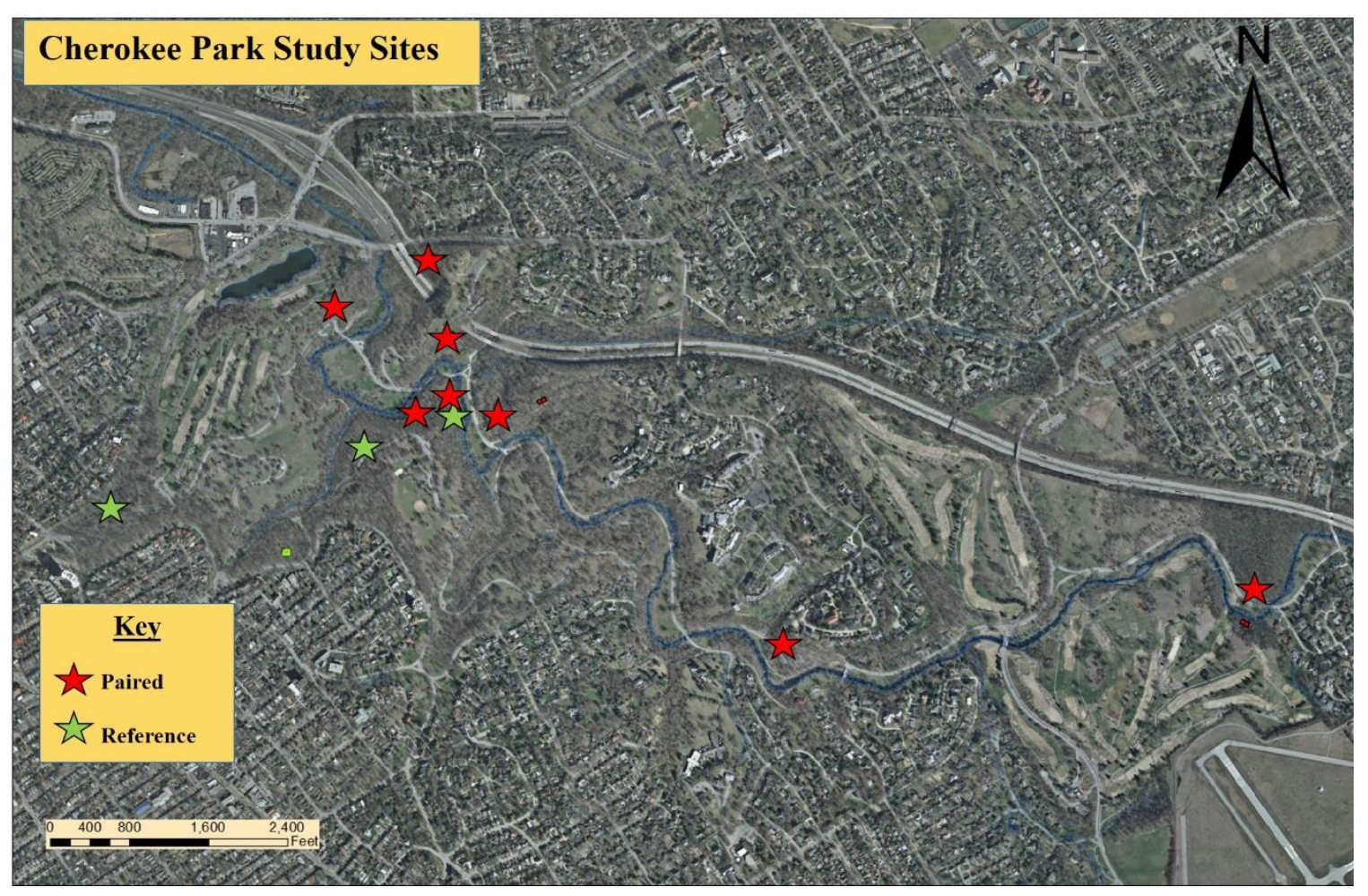

Figure 1. Map of study sites in Cherokee Park Louisville, KY. Red stars are the experimental paired-plot sites. Green stars are reference sites. (See methods section for description of plots). Map source: Louisville Olmsted Parks Conservancy. 


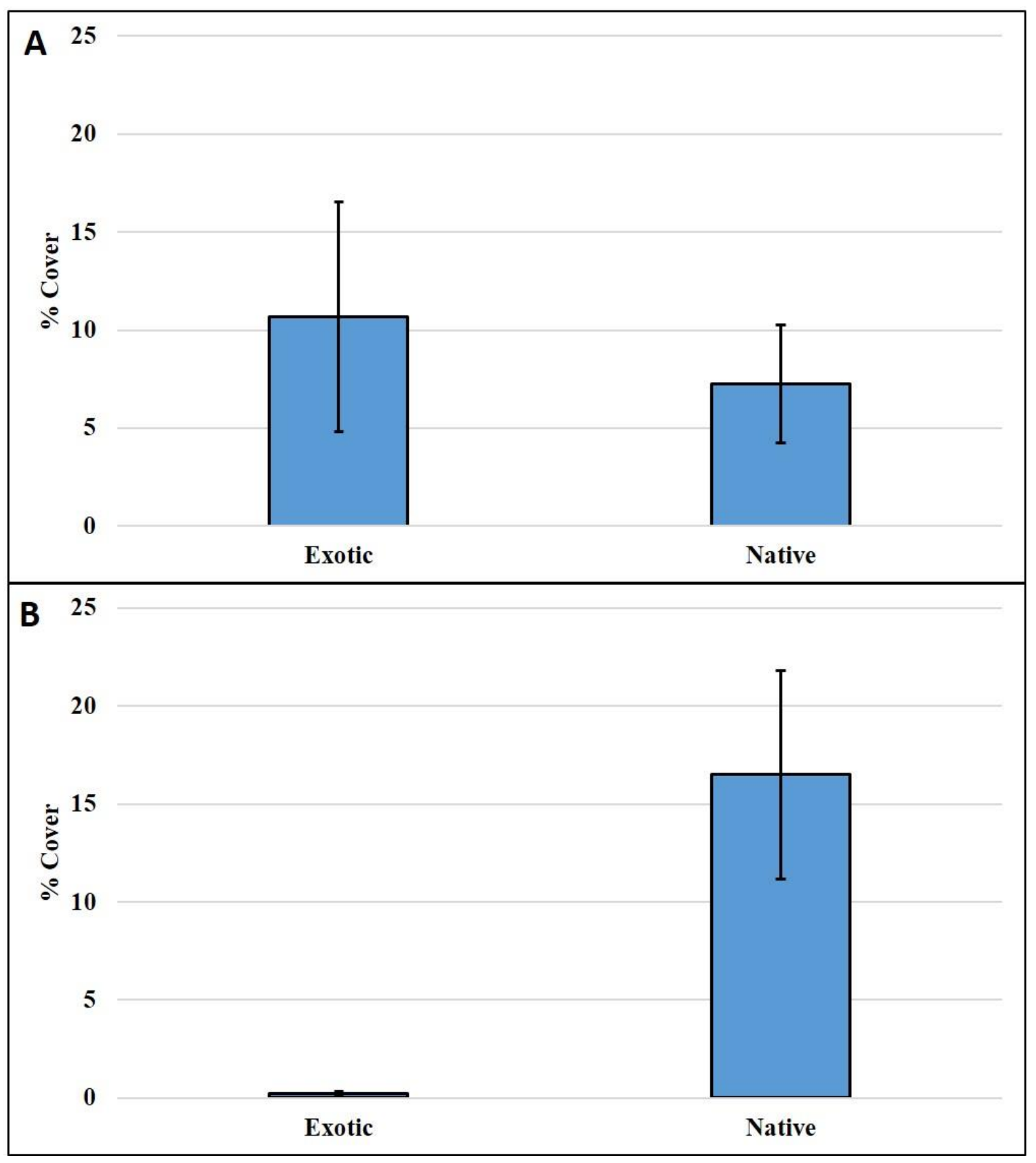

Figure 2. Mean exotic and native herb cover in removal plots during (A) spring and (B) summer 2013. Bars represent mean $( \pm \mathrm{SE})$. Two-tailed pairwise t-tests (Exotic vs Native) Spring: $\mathrm{p}=0.80$; Summer: $\mathrm{p}=$ 0.0038 . $\mathrm{N}=8$. 


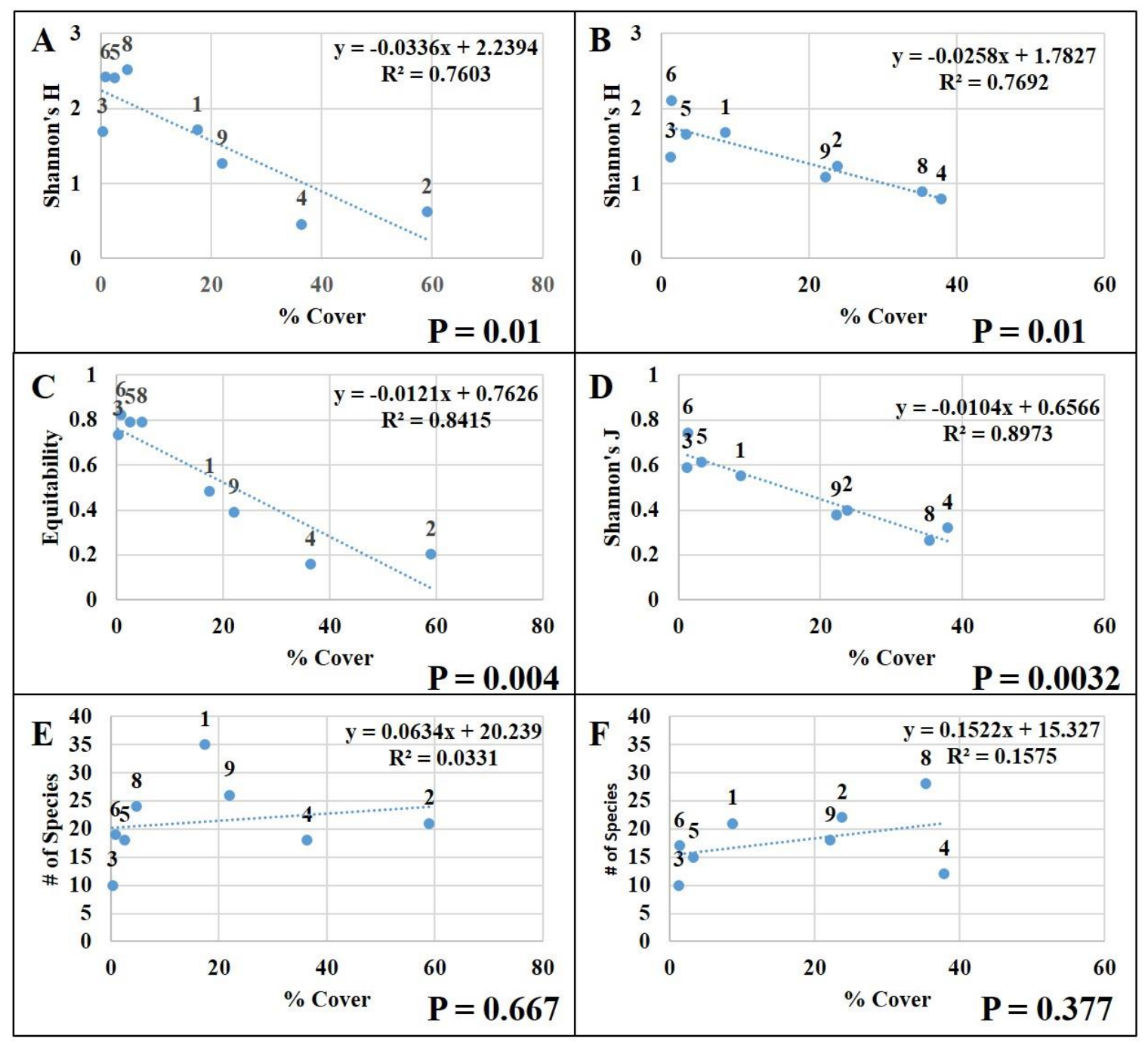

Figure 3. Total herb cover as an explanatory variable for spring (A, C, E) and summer (B, D, F) Diversity, H', (A, B), Evenness, J, (C, D), and species richness, R, (E, F) in removal plots only in 2013. Data points are mean values, labels are site numbers provided for comparison between graphs. P-values are corrected for False Discovery Rate (FDRp) using Proc Multtest (SAS, v9.3). Equation represents the line of best fit calculated using Proc Reg (SAS, v9.3). 


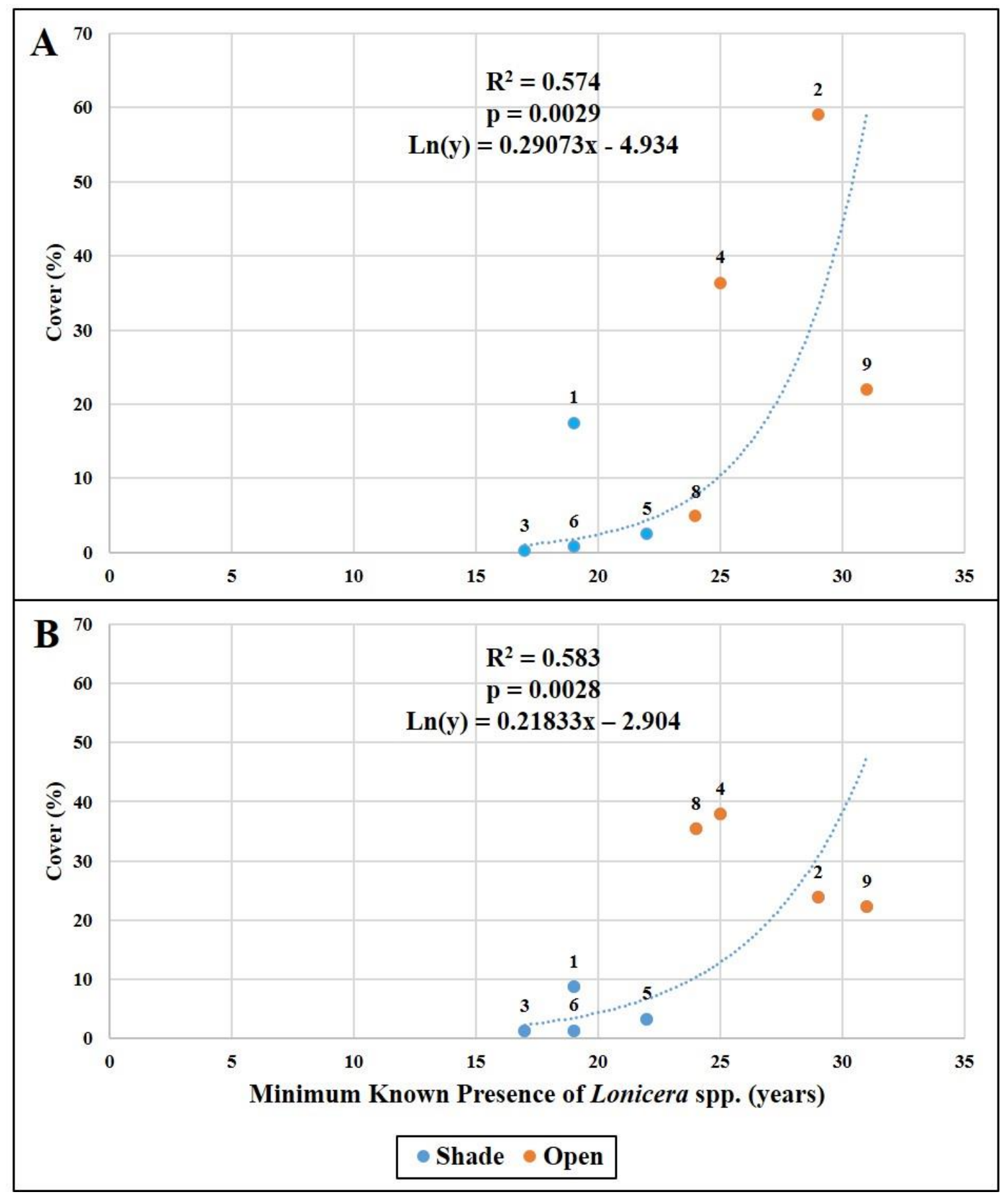

Figure 4. Exponential regressions of herb cover (2013) in removal plots and the minimum known presence of L. maackii prior to removal based on the mean of annual ring counts in two of the largest stems removed per plot. Spring herb cover (A) and summer herb cover (B). Numbers above points indicate plot number. "Shade" plots are those with a more closed tree canopy, "Open" indicates a more open tree canopy. Lines indicate exponential regression line of best fit; P-values were calculated using Proc Reg (SAS, v9.3). 
Appendix 1. Exotic Species among the five most abundant herbs from each control and removal plot in 2013. Spring (A) and Summer (B) herbs in the control (Con.) and removal (Rem.) plots. Values are relative cover (\%) for the most abundant single species in that plot (Top spp.; asterisk,*, indicates the species was exotic), the sum of the five most abundant species (Top 5). Means for relative cover are given $( \pm$ S.E.). Also listed are the number of exotic species present in the five most abundant herbs, and the four letter code for each species counted in the Exotic spp. column: RAFI = Ranunculus ficaria, ALPE $=$ Alliaria petiolata, DUIN $=$ Duchesnea indica, LYSQ $=$ Lycoris squamigera, Arctium minus $=$ ARMI. Nomenclature and native status from USDA PLANTS Database (Natural Resources Conservation Service 2016).

\begin{tabular}{|c|c|c|c|c|c|c|c|c|c|}
\hline $\begin{array}{l}\text { Con. } \\
\text { Plots: }\end{array}$ & $\begin{array}{l}\text { Top } \\
\text { Spp. }\end{array}$ & Top 5 & $\begin{array}{c}\text { Exotic } \\
\text { spp. }\end{array}$ & Exotic spp. & $\begin{array}{l}\text { Rem. } \\
\text { plots }\end{array}$ & $\begin{array}{l}\text { Top } \\
\text { Spp. }\end{array}$ & Top 5 & $\begin{array}{l}\text { Exoti } \\
\text { c spp. }\end{array}$ & Exotic spp. \\
\hline 1 & 49.09 & 85.23 & 1 & RAFI & 1 & $59.01 *$ & 82.77 & 1 & RAFI \\
\hline 2 & $84.73 *$ & 95.94 & 1 & ALPE & 2 & $82.89 *$ & 98.28 & 1 & ALPE \\
\hline 3 & 93.76 & 99.88 & 1 & ALPE & 3 & $31.66 *$ & 91.06 & 2 & $\begin{array}{l}\text { ALPE, } \\
\text { DUIN }\end{array}$ \\
\hline 4 & 97.37 & 99.90 & 2 & $\begin{array}{c}\text { ALPE, } \\
\text { RAFI }\end{array}$ & 4 & 83.50 & 99.98 & 2 & $\begin{array}{l}\text { ALPE, } \\
\text { RAFI }\end{array}$ \\
\hline 5 & 77.72 & 91.98 & 0 & & 5 & 27.55 & 67.59 & 1 & RAFI \\
\hline 6 & 23.60 & 67.37 & 2 & $\begin{array}{l}\text { ALPE, } \\
\text { DUIN }\end{array}$ & 6 & 51.97 & 91.72 & 1 & ALPE \\
\hline 8 & 37.09 & 98.13 & 1 & LYSQ & 8 & 21.35 & 65.42 & 0 & \\
\hline 9 & $81.20 *$ & 92.93 & 1 & ALPE & 9 & $64.63 *$ & 92.92 & 1 & ALPE \\
\hline Mean: & $\begin{array}{c}68.1 \\
(9.79)\end{array}$ & $\begin{array}{c}91.4 \\
(3.85)\end{array}$ & & & Mean: & $\begin{array}{c}52.8 \\
(8.56)\end{array}$ & $\begin{array}{c}86.2 \\
(4.68)\end{array}$ & & \\
\hline
\end{tabular}

B. Summer Herbs

\begin{tabular}{ccccc|ccccc}
\hline $\begin{array}{c}\text { Con. } \\
\text { Plots: }\end{array}$ & $\begin{array}{c}\text { Top } \\
\text { Spp. }\end{array}$ & Top 5 & $\begin{array}{c}\text { Exotic } \\
\text { spp. }\end{array}$ & Exotic spp. & $\begin{array}{c}\text { Rem. } \\
\text { plots }\end{array}$ & $\begin{array}{c}\text { Top } \\
\text { Spp. }\end{array}$ & Top 5 & $\begin{array}{c}\text { Exoti } \\
\text { c spp. }\end{array}$ & Exotic spp. \\
\hline 1 & 25.01 & 86.46 & 0 & ALPE, & 2 & 32.27 & 93.62 & 0 & \\
2 & & & & & & & & ALPE, \\
& 44.26 & 98.41 & 2 & DUIN & & 68.34 & 91.93 & 2 & ARMI \\
3 & & & & & 3 & & & & ALPE, \\
& 100 & 100 & 0 & & & 60.38 & 93.44 & 2 & DUIN \\
4 & 39.18 & 97.48 & 1 & ALPE & 4 & 68.96 & 98.93 & 0 & \\
5 & 57.95 & 95.62 & 1 & ALPE & 5 & 40.81 & 91.78 & 1 & ALPE \\
6 & 48.70 & 90.86 & 1 & ALPE & 6 & 29.67 & 80.59 & 0 & \\
8 & 38.90 & 86.06 & 0 & & 8 & 83.33 & 92.36 & 0 & \\
9 & 31.60 & 91.03 & 1 & ALPE & 9 & 70.27 & 95.78 & 0 & \\
Mean: & 48.2 & 93.24 & & & Mean: & 56.76 & 92.31 & & \\
& $(8.21)$ & $(1.91)$ & & & & $(7.04)$ & $(1.87)$ & & \\
\hline
\end{tabular}




\begin{tabular}{|c|c|c|c|c|c|}
\hline \multicolumn{6}{|c|}{$\begin{array}{l}\text { Appendix 2. Most abundant spring herbs in control and removal plots (2013). Values in Control and } \\
\text { Removal columns are the \# of plots that in which each species was among the five most abundant } \\
\text { species; parentheses enclose total cover in all control and removal plots (\%). Species ordered by plot } \\
\text { presence in "Removal". Timing of reproduction are perennial (P), annual (A), or biennial (B). } \\
\text { Coefficient of Conservatism (CC) for taxa above species provided as a range based on possible species } \\
\text { (Shea et al, unpublished, sensu Swink and Wilhelm 1994). Invasive species are marked with an asterisk } \\
\text { (*); graminoids marked with } \dagger \text {, all others are non-legume forbs. Nomenclature, timing of reproduction, } \\
\text { native status, and forb/legume are based on USDA PLANTS database (Natural Resources Conservation } \\
\text { Service 2016). }\end{array}$} \\
\hline & Comitur & KCIIIV $\mathrm{va}$ & IIIIII) & & Family \\
\hline $\begin{array}{c}\text { Alliaria petiolata (M. Bieb.) } \\
\text { Cavara \& Grande* }\end{array}$ & $5(1.744)$ & $5(8.97)$ & $\mathrm{AB}$ & - & Brassicaceae \\
\hline $\begin{array}{l}\text { Ageratina altissima (L.) R. M. } \\
\text { King \& H. Rob. }\end{array}$ & $2(0.055)$ & $4(0.753)$ & $\mathrm{P}$ & 2 & Asteraceae \\
\hline Geum spp. & $4(0.092)$ & $4(0.275)$ & $\mathrm{P}$ & $2-3$ & Rosaceae \\
\hline Ranunculus ficaria L.* & $2(0.065)$ & $3(2.174)$ & $\mathrm{P}$ & - & Ranunculaceae \\
\hline Cardamine parviflora $\mathrm{L}$. & $0(0.009)$ & $2(1.113)$ & A & 1 & Brassicaceae \\
\hline $\begin{array}{l}\text { Erythronium americanum Ker } \\
\text { Gawl. }\end{array}$ & $2(0.83)$ & $2(0.187)$ & $\mathrm{P}$ & 7 & Liliaceae \\
\hline Carex spp. L. $\dagger$ & $2(0.163)$ & $2(0.059)$ & $\mathrm{P}$ & $3-10$ & Cyperaceae \\
\hline Podophyllum peltatum L. & $1(0.195)$ & $2(0.013)$ & $\mathrm{P}$ & 6 & Berberidaceae \\
\hline Camassia scilloides (Raf.) Cory & 1( & $1(3.08$ & $\mathrm{P}$ & 6 & Liliaceae \\
\hline Hydrophyllum spp. & $2(0.398$ & $1(0.265)$ & $\mathrm{P}$ & 5 & Hydrophyllaceae \\
\hline Trillium sessile L. & $2(0.149)$ & $1(0.16)$ & $\mathrm{P}$ & 5 & Liliaceae \\
\hline Asteraceae / Solidago & $0(0.001)$ & $1(0.125)$ & $\mathrm{P}$ & $1-10$ & Asteraceae \\
\hline $\begin{array}{l}\text { Polygonatum biflorum (Walter) } \\
\text { Elliott }\end{array}$ & $2(1.327)$ & $1(0.113)$ & $\mathrm{P}$ & 5 & Liliaceae \\
\hline Asarum canadense $\mathrm{L}$. & $2(0.115)$ & $1(0.108)$ & $\mathrm{P}$ & 6 & Aristolochiaceae \\
\hline Impatiens spp. & $1(0.089)$ & $1(0.102)$ & A & 2 & Balsaminaceae \\
\hline $\begin{array}{l}\text { Sanicula odorata (Raf.) K.M. } \\
\text { Pryer \& L.R. Phillipe }\end{array}$ & $0(0.009)$ & $1(0.094)$ & $\mathrm{P}$ & 4 & Apiaceae \\
\hline Dicentra spp. & $1(0.047)$ & $1(0.08$ & $\mathrm{P}$ & $6-7$ & Fumariaceae \\
\hline Phytolacca americanum L. & $1(0.009)$ & $1(0.065)$ & $\mathrm{P}$ & 1 & Phytolaccaceae \\
\hline $\begin{array}{l}\text { Duchesnea indica (Andrews) } \\
\text { Focke* }\end{array}$ & $1(0.012)$ & $1(0.061)$ & $\mathrm{P}$ & - & Rosaceae \\
\hline $\begin{array}{l}\text { Verbesina alternifolia (L.) Britton } \\
\quad \text { ex Kearney }\end{array}$ & $1(0.018)$ & $1(0.058)$ & $\mathrm{P}$ & 2 & Asteraceae \\
\hline $\begin{array}{l}\text { Cardamine concatenate Michx. } \\
\quad(\mathrm{Sw} .)\end{array}$ & $1(0.058)$ & $1(0.048)$ & $\mathrm{P}$ & 5 & Brassicaceae \\
\hline Polymnia canadensis L. & $0(0.006)$ & $1(0.024)$ & $\mathrm{P}$ & 4 & Asteraceae \\
\hline $\begin{array}{l}\text { Arabis laevigata (Muhl. ex Willd.) } \\
\text { Poir. }\end{array}$ & $0(0.008)$ & $1(0.014)$ & B & 5 & Brassicaceae \\
\hline Allium spp. & $2(0.052)$ & $0(0.065)$ & & $3-9$ & Liliaceae \\
\hline Arisaema triphyllum L. (Schott) & $1(0.028)$ & $0(0.04)$ & $\mathrm{P}$ & 6 & Araceae \\
\hline Trillium flexipes Raf. & $1(0.7)$ & $0(0.002)$ & $\mathrm{P}$ & 6 & Liliaceae \\
\hline Lycoris squamigera Maxim.* & $1(0.132)$ & $0(0)$ & $\mathrm{P}$ & - & Liliaceae \\
\hline
\end{tabular}


Appendix 3. Most abundant summer herbs in control and removal plots (2013). Values in Control and Removal columns are the number of plots that in which each species was among the five most abundant species; parentheses enclose total cover in all control and removal plots (\%). Species ordered by plot presence in "Removal". Timing of reproduction are perennial (P), annual (A), or biennial (B).

Coefficient of Conservatism (CC) for taxa above species provided as a range based on possible species (Shea et al, unpublished, sensu Swink and Wilhelm 1994). Invasive species are marked with an asterisk, *. Graminoids are marked with $\dagger$; all others are non-legume forbs. Nomenclature, timing of reproduction, native status, and forb/legume are based on USDA PLANTS database (Natural Resources Conservation Service 2016).

\begin{tabular}{|c|c|c|c|c|c|}
\hline & Control & Removal & Timing & $\mathrm{CC}$ & Family \\
\hline \multicolumn{6}{|l|}{ Ageratina altissima (L.) R. M. King } \\
\hline \& H. Rob. & $6(0.445)$ & $7(9.65)$ & $\mathrm{P}$ & 2 & Asteraceae \\
\hline Phytolacca americana $\mathrm{L}$. & $2(0.204)$ & $5(3.99)$ & $\mathrm{P}$ & 1 & Phytolaccaceae \\
\hline Oxalis stricta $\mathrm{L}$. & $0(0)$ & $3(0.189)$ & $\mathrm{P}$ & 0 & Oxalidaceae \\
\hline \multicolumn{6}{|l|}{ Alliaria petiolata (M. Bieb.) Cavara } \\
\hline \& Grande * & $5(0.224)$ & $3(0.141)$ & $\mathrm{AB}$ & - & Brassicaceae \\
\hline Asarum canadense $\mathrm{L}$. & $2(0.353)$ & $2(0.368)$ & $\mathrm{P}$ & 6 & Aristolochiaceae \\
\hline \multicolumn{6}{|l|}{ Verbesina alternifolia (L.) Britton ex } \\
\hline Kearney & $1(0.086)$ & $2(0.228)$ & $\mathrm{P}$ & 2 & Asteraceae \\
\hline Solidago canadensis $\mathrm{L}$. & $1(0.008)$ & $2(0.169)$ & $\mathrm{P}$ & 8 & Asteraceae \\
\hline Geum canadense Jacq. & $3(0.047)$ & $2(0.125)$ & $\mathrm{P}$ & 2 & Rosaceae \\
\hline \multicolumn{6}{|l|}{ Symphyotrichum lateriflorum (L.) Á. } \\
\hline Löve \& D. Löve & $0(0)$ & $2(0.109)$ & $\mathrm{P}$ & 3 & Asteraceae \\
\hline Carex sp. L. $\dagger$ & $2(0.036)$ & $2(0.006)$ & $\mathrm{P}$ & $3-10$ & Cyperaceae \\
\hline \multicolumn{6}{|l|}{ Sanicula odorata (Raf.) K.M. Pryer } \\
\hline \& L. R. Phillipe & $0(0.024)$ & $1(0.275)$ & $\mathrm{P}$ & 4 & Apiaceae \\
\hline Hydrophyllum spp. & $2(0.273)$ & $1(0.266)$ & $\mathrm{P}$ & 5 & Hydrophyllaceae \\
\hline Carex jamesii Schwein $\uparrow$ & $1(0.007)$ & $1(0.14)$ & $\mathrm{P}$ & 6 & Cyperaceae \\
\hline Eupatorium serotinum Michx. & $0(0)$ & $1(0.136)$ & $\mathrm{P}$ & 2 & Asteraceae \\
\hline Arctium minus Bernh.* & $0(0)$ & $1(0.124)$ & B & - & Asteraceae \\
\hline Geum vernum (Raf.) Torr. \& A. Gray & $2(0.034)$ & $1(0.119)$ & $\mathrm{P}$ & 3 & Hydrophyllaceae \\
\hline \multicolumn{6}{|l|}{ Duchesnea indica (Andrews) Focke } \\
\hline$*$ & $1(0.024)$ & $1(0.104)$ & $\mathrm{P}$ & - & Rosaceae \\
\hline Impatiens spp. L. & $1(0.02)$ & $1(0.092)$ & A & 2 & Balsaminaceae \\
\hline Arisaema triphyllum L. (Schott) & $1(0.029)$ & $1(0.071)$ & $\mathrm{P}$ & 6 & Araceae \\
\hline Carex blanda Dewey $\dagger$ & $1(0.004)$ & $1(0.024)$ & $\mathrm{P}$ & 2 & Cyperaceae \\
\hline \multicolumn{6}{|l|}{ Polygonatum biflorum (Walter) } \\
\hline Elliott & $0(0)$ & $1(0.021)$ & $\mathrm{P}$ & 5 & Liliaceae \\
\hline Hypericum punctatum Lam. & $0(0)$ & $1(0.012)$ & $\mathrm{P}$ & 1 & Clusiaceae \\
\hline Stellaria pubera Michx. & $1(0.037)$ & $0(0.012)$ & $\mathrm{P}$ & 4 & Caryophyllaceae \\
\hline Collinsonia candensis $\mathrm{L}$. & $1(0.199)$ & $0(0.001)$ & $\mathrm{P}$ & 7 & Lamiaceae \\
\hline Laportea canadensis (L.) Weddell & $1(0.176)$ & $0(0)$ & $\mathrm{P}$ & 4 & Urticaceae \\
\hline \multicolumn{6}{|l|}{ Polystichum acrostichoides (Michx.) } \\
\hline Schott. & $1(0.018)$ & $0(0)$ & $\mathrm{P}$ & 4 & Dryopteridaceae \\
\hline
\end{tabular}


Appendix 4. Tree seedling species incidence in 2013. All seedling species and the number of plots in which they were present in 2013. Percent (\%) values are percent of total tree seedlings found in 2013 were represented by that species. Species ordered by percent of total tree seedlings. Species marked with an asterisk $(*)$ are exotic, those marked with $\dagger$ were found only in Reference plots in 2013.

Nomenclature and native status are based on USDA PLANTS database (Natural Resources Conservation Service 2016).

\begin{tabular}{|c|c|c|c|c|}
\hline \multirow[b]{2}{*}{ Spp. } & \multicolumn{3}{|c|}{ Plots Present } & \multirow[b]{2}{*}{$\%$} \\
\hline & Control & Removal & Reference & \\
\hline Fraxinus pennsylvanica Marshall & 6 & 5 & 2 & 30.0 \\
\hline Fraxinus spp. L. & 7 & 7 & 2 & 20.0 \\
\hline Acer saccharum Marshall & 4 & 4 & 3 & 11.6 \\
\hline Rhamnus cathartica L. * & 5 & 6 & 0 & 8.71 \\
\hline Acer negundo L. & 7 & 7 & 2 & 6.72 \\
\hline Prunus serotina Ehrh. & 6 & 6 & 3 & 5.91 \\
\hline Celtis occidentalis L. & 8 & 7 & 3 & 5.85 \\
\hline Koelreutaria paniculata Laxm. * & 1 & 1 & 0 & 4.71 \\
\hline Fraxinus americana $\mathrm{L}$. & 2 & 4 & 0 & 3.58 \\
\hline Ulmus rubra Muhl. & 7 & 5 & 2 & 0.827 \\
\hline Asimina triloba (L.) Dunal & 2 & 1 & 1 & 0.346 \\
\hline Cercis canadensis $\mathrm{L}$. & 1 & 2 & 0 & 0.331 \\
\hline Juniperus virginiana $\mathrm{L}$. & 1 & 2 & 0 & 0.226 \\
\hline Crataegus sp. L. & 2 & 4 & 0 & 0.165 \\
\hline Ailanthus altissima (Mill.) Swingle* & 1 & 0 & 0 & 0.150 \\
\hline Fraxinus quadrangulata Michx. & 0 & 4 & 1 & 0.150 \\
\hline Carya sp. Nutt & 2 & 3 & 1 & 0.135 \\
\hline Juglans nigra L. & 1 & 0 & 1 & 0.120 \\
\hline Quercus sp. L. & 3 & 4 & 0 & 0.120 \\
\hline Ilex sp. L. & 2 & 2 & 0 & 0.105 \\
\hline Carpinus caroliniana Walter & 1 & 1 & 0 & 0.090 \\
\hline Aesculus glabra Willd. & 1 & 1 & 2 & 0.060 \\
\hline Fagus grandifolia Ehrh. & 0 & 1 & 2 & 0.060 \\
\hline Morus rubra L. & 0 & 1 & 0 & 0.030 \\
\hline Morus sp. L. & 0 & 1 & 0 & 0.015 \\
\hline Robinia psudeoacia L. & 0 & 1 & 0 & 0.015 \\
\hline Morus alba L. *† & 0 & 0 & 1 & 0.015 \\
\hline
\end{tabular}


Appendix 5. Tree sapling species incidence in 2013. All sapling species and the number of plots in which they were present in 2013. Percent (\%) values are percent of total saplings found in 2013 were represented by that species. Species ordered by percent of total tree seedlings. Species marked with an asterisk $(*)$ are exotic, those marked with $\dagger$ were found only in Reference plots in 2013. Nomenclature and native status are based on USDA PLANTS database (Natural Resources Conservation Service 2016).

\begin{tabular}{|c|c|c|c|c|}
\hline \multirow[b]{2}{*}{ Sapling Species } & \multicolumn{3}{|c|}{ Plots Present } & \multirow[b]{2}{*}{$\%$} \\
\hline & Control & Removal & Reference & \\
\hline Acer negundo $\mathrm{L}$ & 3 & 7 & 3 & 26.9 \\
\hline Fraxinus pennsylvanica Marshall & 2 & 5 & 2 & 25.0 \\
\hline Asimina triloba (L.) Dunal & 2 & 1 & 1 & 13.6 \\
\hline Acer saccharum Marsh. & 4 & 4 & 1 & 8.54 \\
\hline Prunus serotine Ehrh. & 2 & 2 & 1 & 7.09 \\
\hline Fraxinus americana $\mathrm{L}$. & 2 & 3 & 0 & 5.64 \\
\hline Rhamnus cathartica $\mathrm{L}$. & 3 & 2 & 0 & 4.78 \\
\hline Celtis occidentalis L. & 1 & 6 & 2 & 2.32 \\
\hline Aesculus glabra Willd. & 2 & 2 & 3 & 1.45 \\
\hline Koelreuteria paniculata Laxm*. & 1 & 1 & 0 & 1.01 \\
\hline Acer rubrum $\mathrm{L}$. & 0 & 1 & 0 & 0.579 \\
\hline Morus alba L. * & 0 & 1 & 1 & 0.579 \\
\hline Cercis canadensis L. & 0 & 2 & 0 & 0.289 \\
\hline Fagus grandifolia Ehrh. $\dagger$ & 0 & 0 & 1 & 0.289 \\
\hline Fraxinus quadrangulata Michx. & 2 & 0 & 0 & 0.289 \\
\hline Juglans nigra $\mathrm{L} . \dagger$ & 0 & 0 & 1 & 0.289 \\
\hline Morus rubra $\mathrm{L}$. & 0 & 2 & 0 & 0.289 \\
\hline Robinia pseudoacacia L. & 0 & 1 & 0 & 0.289 \\
\hline Carya alba (Lam.) Nutt. & 0 & 1 & 0 & 0.145 \\
\hline Carya sp. Nutt. $\dagger$ & 0 & 0 & 1 & 0.145 \\
\hline Fraxinus sp. L. & 1 & 0 & 0 & 0.145 \\
\hline Pyrus calleryana Decne. * & 1 & 0 & 0 & 0.145 \\
\hline
\end{tabular}


Appendix 6. Shrub species incidence in 2013. All shrub species distributed by stems $>30 \mathrm{~cm}(\mathrm{~A})$ and seedlings (B) in all plots in which they were present in 2013. Percent values are percent of total stems or seedlings found in 2013 that were of that species. Species are ordered by $\%$ of stems. Exotic species are marked with an asterisk (*). Nomenclature and native status are based on USDA PLANTS database (Natural Resources Conservation Service 2016).

\begin{tabular}{|c|c|c|c|c|}
\hline \multicolumn{5}{|l|}{ A. } \\
\hline \multirow[b]{2}{*}{ Species } & \multicolumn{3}{|c|}{ Plots Present } & \multirow[b]{2}{*}{$\%$ of stems } \\
\hline & Control & Removal & Reference & \\
\hline Lonicera spp. L. * & 8 & 8 & 2 & 80.6 \\
\hline Ligustrum sp. L.* & 5 & 6 & 0 & 17.7 \\
\hline Staphylea trifolia $\mathrm{L}$ & 0 & 1 & 0 & 0.934 \\
\hline Lindera benzoin (L.) Blume & 1 & 1 & 1 & 0.682 \\
\hline Viburnum sp. L. & 0 & 1 & 0 & 0.036 \\
\hline Rubus sp. L.* & 0 & 1 & 0 & 0.018 \\
\hline $\begin{array}{l}\text { Sambucus canadensis (L) R. } \\
\quad \text { Bolli }\end{array}$ & 1 & 0 & 0 & 0.018 \\
\hline B. & \multicolumn{3}{|c|}{ Plots Present } & \\
\hline Species & Control & Removal & Reference & $\%$ of seedlings \\
\hline \multicolumn{5}{|l|}{ Lonicera maackii (Rupr.) } \\
\hline Herder * & 8 & 8 & 2 & 93.2 \\
\hline Lindera benzoin (L.) Blume & 2 & 2 & 2 & 3.79 \\
\hline Ligustrum sp. L. * & 4 & 3 & 0 & 1.78 \\
\hline \multicolumn{5}{|l|}{ Sambucus canadensis (L) R. } \\
\hline Bolli & 1 & 0 & 2 & 0.746 \\
\hline Rubus sp. L. * & 1 & 2 & 0 & 0.229 \\
\hline Staphylea trifolia $\mathrm{L}$ & 1 & 1 & 0 & 0.229 \\
\hline $\begin{array}{l}\text { Lonicera fragrantisisma Lindl. } \\
\text { \& Paxton* }\end{array}$ & 1 & 0 & 0 & 0.057 \\
\hline
\end{tabular}


Appendix 7. Summer (2013) herb incidence in "shade" and "open" removal plots. Herbs are the most abundant species as per Appendix 3. Values in plots present are the number of removal plots from the "shade" or "open" categories where the species was present, while \% cover is the amount of cover for that herb in each category. Species are ordered by highest \% cover in the "Open" column. Species marked with an asterisk $(*)$ are exotic; those marked with $\dagger$ are graminoids, all other species are nonlegume forbs. Nomenclature, native status, and forb/legume are based on USDA PLANTS database (Natural Resources Conservation Service 2016).

\begin{tabular}{|c|c|c|c|c|c|}
\hline \multirow[b]{2}{*}{ Species: } & \multicolumn{2}{|c|}{ Plots present } & \multicolumn{2}{|c|}{$\%$ cover } & \multirow[b]{2}{*}{ Family } \\
\hline & "Shade" & "Open" & "Shade" & "Open" & \\
\hline $\begin{array}{l}\text { Ageratina altissima }(\mathrm{L} .) \text { R. } \\
\text { M. King \& H. Rob. }\end{array}$ & 4 & 4 & 0.549 & 18.8 & Asteraceae \\
\hline Phytolacca americana $\mathrm{L}$. & 2 & 3 & 0.529 & 7.45 & Phytolaccaceae \\
\hline $\begin{array}{l}\text { Verbesina alternifolia }(\mathrm{L} .) \\
\text { Britton ex Kearney }\end{array}$ & 1 & 1 & 0.043 & 0.413 & Asteraceae \\
\hline Solidago canadensis L. & 1 & 4 & 0.014 & 0.325 & Asteraceae \\
\hline Oxalis stricta $\mathrm{L}$. & 3 & 4 & 0.057 & 0.321 & Oxalidaceae \\
\hline Carex jamesii Schwein.† & 2 & 2 & 0.007 & 0.274 & Cyperaceae \\
\hline Eupatorium serotinum Michx. & 0 & 2 & 0 & 0.273 & Asteraceae \\
\hline Arctium minus Bernh.* & 0 & 1 & 0 & 0.248 & Asteraceae \\
\hline $\begin{array}{l}\text { Geum vernum (Raf.) Torr. \& } \\
\text { A. Gray }\end{array}$ & 1 & 4 & 0.005 & 0.233 & Asteraceae \\
\hline $\begin{array}{l}\text { Symphyotrichum lateriflorum } \\
\text { (L.) Á. Löve \& D. Löve }\end{array}$ & 0 & 3 & 0 & 0.218 & Asteraceae \\
\hline Geum canadense Jacq. & 2 & 3 & 0.034 & 0.216 & Asteraceae \\
\hline $\begin{array}{l}\text { Alliaria petiolata (M. Bieb.) } \\
\text { Cavara \& Grande * }\end{array}$ & 4 & 4 & 0.078 & 0.203 & Brassicaceae \\
\hline $\begin{array}{l}\text { Duchesnea indica (Andrews) } \\
\text { Focke * }\end{array}$ & 2 & 4 & 0.04 & 0.168 & Rosaceae \\
\hline Impatiens spp. L. & 4 & 2 & 0.092 & 0.093 & Balsaminaceae \\
\hline Carex blanda Dewey $\dagger$ & 2 & 2 & 0.025 & 0.023 & Cyperaceae \\
\hline Carex spp. L. $\dagger$ & 2 & 1 & 0.005 & 0.008 & Cyperaceae \\
\hline Asarum canadense $\mathrm{L}$. & 2 & 0 & 0.735 & 0 & Aristolochiaceae \\
\hline Hydrophyllum spp. L. & 2 & 0 & 0.532 & 0 & Hydrophyllaceae \\
\hline $\begin{array}{l}\text { Arisaema triphyllum } \mathrm{L} . \\
\quad \text { (Schott) }\end{array}$ & 2 & 0 & 0.142 & 0 & Araceae \\
\hline Hypericum punctatum Lam. & 1 & 0 & 0.025 & 0 & Clusiaceae \\
\hline $\begin{array}{l}\text { Polygonatum biflorum } \\
\text { (Walter) Elliott }\end{array}$ & 1 & 0 & 0.043 & 0 & Liliaceae \\
\hline $\begin{array}{l}\text { Sanicula odorata (Raf.) K.M. } \\
\text { Pryer \& L. R. Phillipe }\end{array}$ & 1 & 0 & 0.55 & 0 & Apiaceae \\
\hline Collinsonia candensis L. & 1 & 0 & 0.002 & 0 & Lamiaceae \\
\hline Stellaria pubera Michx. & 1 & 0 & 0.024 & 0 & Caryophyllaceae \\
\hline
\end{tabular}




\title{
CURRICULUM VITA
}

NAME: $\quad$ Elihu H. Levine

\author{
ADDRESS: 2121 Wrocklage Ave. \\ Louisville, KY 40205 \\ DOB: $\quad$ Baltimore, MD - August 23, 1983 \\ EDUCATION \\ \& TRAINING: B.A. Biology \\ Earlham College \\ 2001-2005 \\ M.S. Biology \\ University of Louisville \\ 2008-2016
}

PROFESSIONAL SOCIETIES: Kentucky Academy of Science

Society for Ecological Restoration

INVITED PRESENTATION: Poster presented to the Kentucky Academy of Science's annual conference in November 2008

Levine, E. H. (2008) Patterns of soil diversity and erosion in an urban woodland park.

Presentations to Kentucky Academy of Science's annual conferences:

Levine, E. H. and M. M. Carriero (2015) Plant community responses to the removal of Lonicera maackii in an urban woodland park. Kentucky Academy of Science Meeting, 2015.

Levine, E. H. and M. M. Carriero (2015) Plant community responses to the removal of invasive shrub honeysuckle (Lonicera maackii) in an urban woodland differs by stratum and duration of shrub occupancy. Kentucky Academy of Science Meeting, 2016. 